\title{
Climatic disaster at the Triassic-Jurassic boundary - a clay minerals and major elements record from the Polish Basin
}

\author{
Paweł BRAŃSKI ${ }^{1, *}$ \\ 1 Polish Geological Institute - National Research Institute, Rakowiecka 4, 00-975 Warszawa, Poland
}

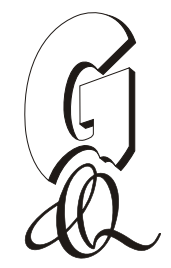

Brański, P., 2014. Climatic disaster at the Triassic-Jurassic boundary - a clay minerals and major elements record from the Polish Basin. Geological Quarterly, 58 (2): 291-310, doi: 10.7306/gq.1161

\begin{abstract}
The Triassic-Jurassic boundary interval (ca. $201 \mathrm{Ma}$ ) was a time of sudden global environmental changes triggered by Pangea breakup and Central Atlantic Magmatic Province development. The bulk-rock mineralogy, clay mineralogy and major element geochemistry of 87 continental mudrock samples collected from four borehole cores yield information on Rhaetian-earliest Hettangian palaeoclimatic changes in the Polish Basin. During the Rhaetian, smectite preponderance was replaced by kaolinite and illite domination. This fundamental shift in clay mineral assemblages (supported by major element data) indicates very significant change in climate humidity. Moreover, some beds in the Zagaje Formation (Upper Rhaetian-Lower Hettangian) are particularly rich in kaolinite indicating extreme chemical weathering in humid-subtropical to tropical climate episodes in the aftermath of powerful warming and abundant rainfall. Importantly, the first distinct kaolinite enrichment appears already in the Lower Rhaetian Wielichowo Beds. In addition, abrupt and episodic shifts in the kaolinite-illite ratio and in values of weathering indices point to profound climate destabilisation and a sequence of frequent, catastrophic climatic reversals in the Late Rhaetian and at the Triassic-Jurassic boundary. These results are generally consistent with carbon isotope records in sections worldwide.
\end{abstract}

Key words: Triassic-Jurassic boundary, clay minerals, major elements, weathering regime, palaeoclimatic shifts, Polish Basin.

\section{INTRODUCTION}

The end of the Triassic and the Triassic-Jurassic transition (ca. $201 \mathrm{Ma}$ ) was a period of sudden global environmental changes linked to the Pangea breakup (Wilson, 1997) and to development of the giant Central Atlantic Magmatic Province (CAMP; Marzoli et al., 1999; Hames et al., 2000; Courtillot and Renne, 2003). Characteristic features of this time were profound perturbations in the global biogeochemical cycle, an increase in atmospheric $\mathrm{CO}_{2}$ content, global greenhouse warming, and mass extinction. The Triassic-Jurassic boundary (TJB) is characterized by pronounced negative excursions in marine and terrestrial carbon isotope records (e.g., Pálfy et al., 2001; Hesselbo et al., 2002; Guex et al., 2004; Ward et al., 2004; Galli et al., 2005; Williford et al., 2007; Ruhl et al., 2009; Deenen et al., 2010; Whiteside et al., 2010; Pieńkowski et al., 2012) as well as perturbations to other isotopic systems (Cohen and Coe, 2002, 2007; Kuroda et al., 2010; Callegaro et al., 2012; Pieńkowski et al., 2012) . A major Late Rhaetian "initial" negative $C$ isotope excursion (initial $\mathrm{CIE}$ ) is usually separated from a subsequent long-term Hettangian "main" negative $C$ isotope excursion (main CIE) by a distinct positive shift in $\delta^{13} \mathrm{C}$ val-

\section{*E-mail: pawel.branski@pgi.gov.pl}

Received: July 07, 2013; accepted: January 05, 2014; first published online: April 03, 2014 ues (Hesselbo et al., 2002, 2007; Schootbrugge et al., 2008; Korte et al., 2009; Pieńkowski et al., 2012; Fig. 1). CAMP development and related processes (volcanic degassing, thermogenic methane release, methane hydrate dissociation) are commonly inferred as triggers of biogeochemical cycle destabilization, climate shifts and other global environmental changes which in turn led to TJB mass extinction. Alternative hypotheses considered changes in palaeoceanography (Hallam and Wignall, 1999) and extraterrestrial impact (Olsen et al., 2002; Simms, 2003). Some authors have focused on ocean acidification and a biocalcification crisis (Hautmann, 2004; Hautmann et al., 2008; Racki, 2010; Richoz et al., 2012). However, increasing precision of stratigraphic correlation links these events to the onset of CAMP volcanism (Marzoli et al., 2004, 2011; Nomade et al., 2007; Cirilli et al., 2009; Jourdan et al., 2009; Deenen et al., 2010; Kozur and Weems, 2010; Ruhl et al., 2010; Schoene et al., 2010; Whiteside et al., 2010; Blackburn et al., 2013).

Rising atmospheric carbon dioxide concentrations likely caused global climate changes and a Late Rhaetian super-greenhouse (McElwain et al., 1999; Whiteside et al., 2010; Schaller et al., 2011, 2012; Steinthorsdottir et al., 2011). Brief but extreme greenhouse events may have been related to massive injections of isotopically light carbon from oceanic methane hydrate destabilization and its cumulative input into the atmosphere and ocean (Beerling and Berner, 2002; Hesselbo et al., 2000, 2007; Ruhl et al., 2011). Some authors, though, have recently challenged the causal link between end-Triassic methane release and terrestrial ecosystem crisis 


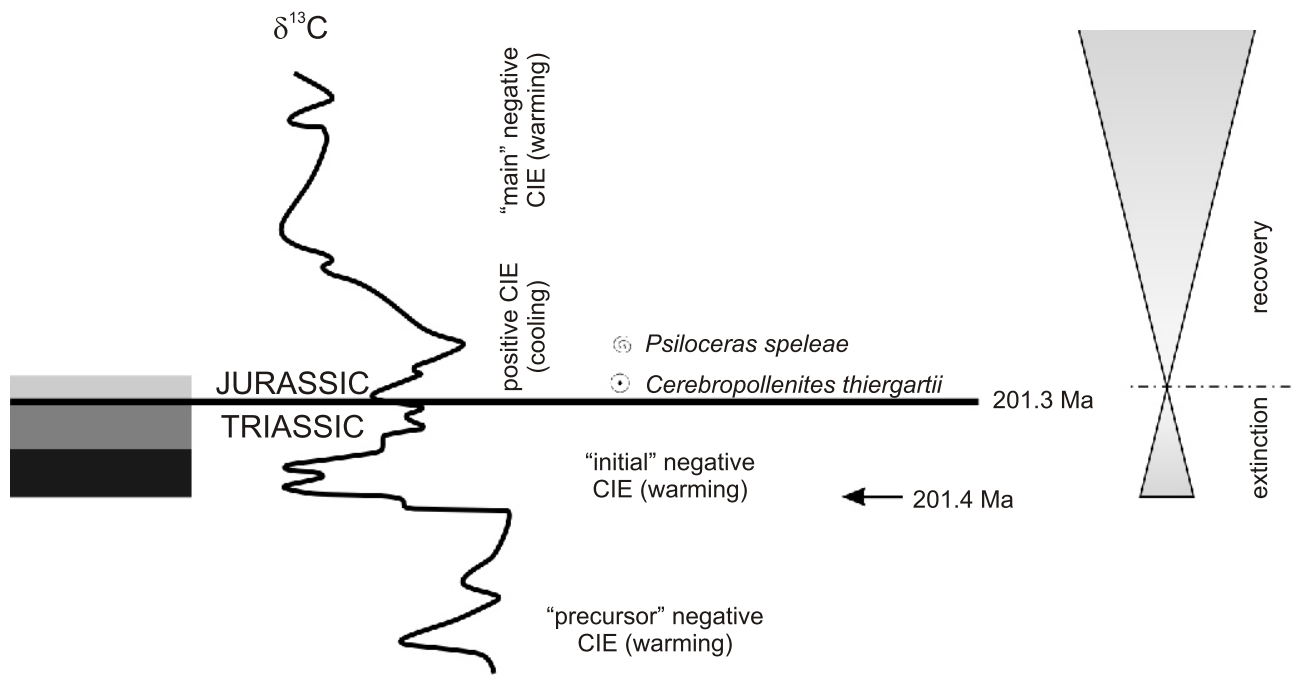

Fig. 1. Cartoon summarising stratigraphy of the Triassic-Jurassic boundary interval adopted in this paper (not to scale)

Generalized carbon-isotope curve and palaeoclimatic changes are modified and compiled from Hesselbo et al. (2002), Korte et al. (2009), Ruhl et al. (2009, 2011), Ruhl and Kürschner (2011) and Pieńkowski et al. (2012). Triassic-Jurassic boundary location is adapted from Korte et al. (2009), and Pieńkowski et al. (2012), FAD of Psiloceras speleae and Cerebropollenites thiergartii from Hillebrandt et al. (2007), and age of "initial" negative CIE from Whiteside et al. (2010), and Ruhl et al. (2010); black strip - the oldest CAMP basalt flow in the Argana Basin, Morocco (Marzoli et al., 2004; Whiteside et al., 2010), dark grey strip - the oldest CAMP basalt flow in the Newark and Hartford basins, Northern America (Olsen et al., 2002; Whiteside et al., 2010), light grey strip - the succeeding basalt flow in the Argana Basin, Morocco (Marzoli et al., 2004; Whiteside et al., 2010)

(Lindström et al., 2012). Indeed, the greenhouse effect as a single cause of terrestrial extinctions is challenged by many authors, who emphasize environmental stress caused by emission of volcanogenic toxic compounds, soil acidification and successive rapid climatic reversals (Self et al., 2006; Ganino and Arndt, 2009; Schootbrugge et al., 2009; Racki, 2010; Pieńkowski et al., 2012, 2014; Schaller et al., 2012). Moreover, it was found that atmospheric $\mathrm{CO}_{2}$ concentrations had increased earlier in the Rhaetian (Cleveland et al., 2008; Bonis et al., 2010). The earlier Rhaetian negative carbon isotope excursions clearly preceded the Late Rhaetian "initial" negative CIE (Ruhl and Kürschner, 2011; Suan et al., 2011; Lindström et al., 2012; Pieńkowski et al., 2012, 2014; Fig. 1). The substantial increase in global temperature, abundant rainfall and an enhanced hydrological cycle caused a large increase in continental weathering and in sediment supply. The Sr-isotope and Os-isotope records indicate that erosion and weathering of CAMP rocks started in the Hettangian, soon after their emplacement (Cohen and Coe, 2002, 2007). Recently some authors indicate two significant shifts of the Os-isotope curve (Kuroda et al., 2010; Pieńkowski et al., 2012) during the Rhaetian that may be attributed to a rapid emplacement of the CAMP, followed by a rapid increase in continental weathering.

Clay deposits in sedimentary basins represent a final product of the continental weathering process and they may reveal climatic fluctuations on continents, if diagenetic transformations were not very significant (e.g., Singer, 1984; Chamley, 1989; Ruffell et al., 2002; Ahlberg et al., 2003; Deconinck et al., 2003; Raucsik and Varga, 2008; Brański, 2009, 2010, 2012; Dera et al., 2009; Hesselbo et al., 2009). In particular, the variations in detrital kaolinite content in the clay fraction are considered as a reliable proxy for humidity. It should be remembered that beside diagenesis, other factors (such as tectonic rejuvenation, sea level changes, and the lithology of the parent rocks) may also influence the clay mineral proportions to some extent (e.g.,
Thiry, 2000; Brański, 2007a, 2012; Hesselbo et al., 2009; Liu et al., 2012; Lintnerová et al., 2013). Abundance of major elements is intimately related to the mineralogy of the mudrocks (Weaver, 1989). The clay mineralogy of Rhaetian-Hettangian sections from Central and Northern Europe has been described in several papers with diverse accuracy (Ahlberg et al., 2002, 2003; Raucsik and Varga, 2008; Michalík et al., 2010; Haas et al., 2012; Pálfy and Zajzon, 2012; Zajzon et al., 2012). Scarce previous data from the southeastern part of the Polish Basin were collected by the present author few years ago (Brański, 2009).

The aim of the present paper is to infer climatic changes from the Rhaetian-Early Hettangian succession in the Polish Basin on the basis of borehole sections that have mostly high sampling resolution. Changes in weathering regime reflecting palaeoclimate shifts are here determined on the basis of variations in clay mineralogy (especially kaolinite content) and major element chemistry. Special attention is paid to abrupt changes in mineralogy and geochemistry, which may reflect catastrophic events.

\section{GEOLOGICAL AND PALAEOGEOGRAPHICAL BACKGROUND}

The epicontinental Polish Basin represents the eastern arm of the Central European Basin System (Pieńkowski and Schudack, 2008). The Mid-Polish Trough (MPT), the axial zone of the Polish Basin, was an elongated relatively narrow subsiding area, running generally along the Teisseyre-Tornquist Zone (TTZ). The MPT was superimposed on the southwestern edge of the East European Craton and the northeastern boundary of the Variscides (Dadlez, 1997; Fig. 2). At the very beginning of the Jurassic the basin depocenter was finally placed along the MPT. In 


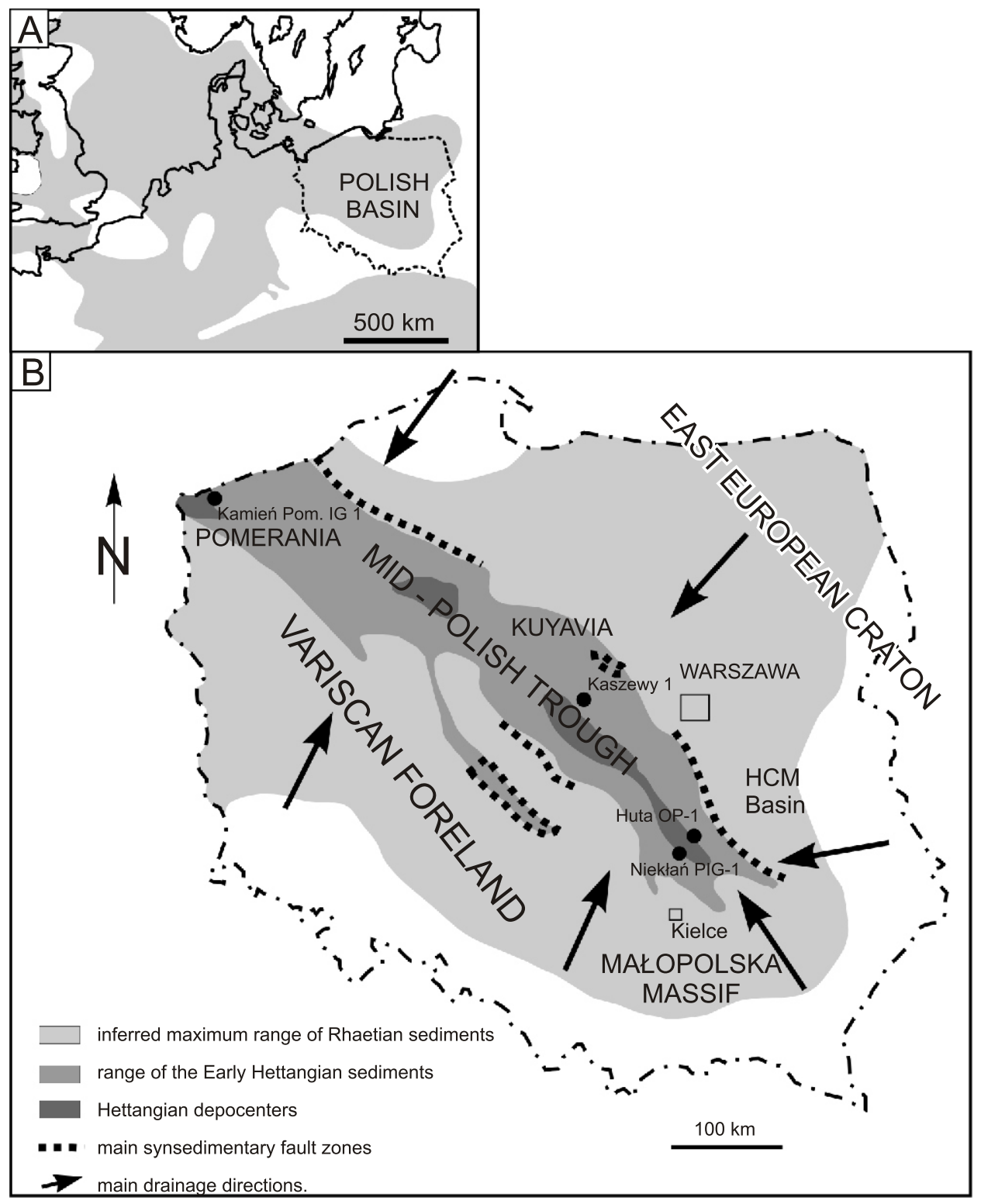

Fig. 2. General palaeogeography and location of study area (modified after Pieńkowski et al., 2014)

A - extent of the Rhaetian basins in Central and Northwestern Europe;

B - palaeogeographic map of the Rhaetian-Early Hettangian basin in Poland with locations of profiles sampled; $\mathrm{HCM}$ - Holy Cross Mountains

Late Rhaetian-Early Hettangian times the distance from the nearest CAMP volcanic eruptions to the Polish Basin did not exceed 1500 km (Pieńkowski et al., 2014). The Rhaetian was a tectonically quiet time, but at the beginning of the Hettangian there was a distinct fault-related tectonic event (Hakenberg and Świdrowska, 1997; Poprawa, 1997; Pieńkowski, 2004). In the earliest Hettangian, a short-lived but pronounced transtension-related subsidence pulse was superimposed (Brański, 2006, 2011a) on the long-term thermal subsidence of the Polish Basin (Dadlez et al., 1995; Stephenson et al., 2003). The axial part of the basin was affected by a number of faults, grabens and half-grabens (Dadlez et al., 1998). The phase of synsedimentary faulting was accompanied (especially in the southeastern area), by rapid accumulation that was, however, restricted to the MPT and local grabens (Brański, 2006, 2011a).

The Triassic-Jurassic boundary in the Polish Basin is located between the last appearance datum (LAD) of the megaspore Trileites pinguis (Marcinkiewicz, 1971) and the first appearance datum (FAD) of Cerebropollenites thiergartii in the Kamień Pomorski profile (Pieńkowski et al., 2012). However, biostratigrahical resolution of the Rhaetian-Lower Hettangian succession is unsatisfactory. Nevertheless, the epicontinental basin in Poland may be assigned to the European stratigraphic framework on the basis of high-resolution sequence stratigraphy (Pieńkowski, 2004) and chemostratigraphy (Pieńkowski et al., 2012, 2014).

The Late Norian deposits in the Polish Basin represent a red-bed association (mostly mudstones and siltstones) with rare calcretes and carbonate nodules, which are assigned to the Zbąszynek Beds. Two lithostratigraphic units are distinguished within the Triassic-Jurassic transitional section (Table 1): the Lower-Middle Rhaetian Wielichowo Beds and the Upper Rhaetian-Lower Hettangian Zagaje Formation (Pieńkowski et al., 2012). The Wielichowo Beds rest on the erosional sequence 
Table 1

Stratigraphy of the Triassic-Jurassic transition in the epicontinental Polish Basin (after Pieńkowski et al., 2012)

\begin{tabular}{|c|c|c|c|}
\hline System & Stage & \multicolumn{2}{|c|}{ Formation } \\
\hline $\begin{array}{l}\text { JURASSIC } \\
201.3 \mathrm{Ma}\end{array}$ & Hettangian & Lower & \multirow[t]{2}{*}{ Zagaje Formatior } \\
\hline \multirow{3}{*}{ TRIASSIC } & \multirow{2}{*}{ Rhaetian } & Upper & \\
\hline & & Lower-Middle & Wielichowo Beds \\
\hline & Norian & Upper & Zbąszynek Beds \\
\hline
\end{tabular}

Dashed lines - major erosional surfaces (sequence boundaries)

boundary between Norian and Rhaetian deposits, which coincides with Early Cimmerian unconformity (Pieńkowski, 2004). This unit is mostly represented by red-brownish, greenish or multicoloured mottled mudstones, with calcium carbonate concretions (Pieńkowski et al., 2012). The Zagaje Formation lies above an erosional sequence boundary (Pieńkowski, 2004), which is probably concomitant with the Rhaetian lowstand (Pieńkowski et al., 2012). This unit comprises mostly grey sandstone, mudstone, claystone and palaeosols with siderite concretions, coalified plant roots and floral remains. The upper part of the Zagaje Formation (Hettangian) is preceded by conspicuous erosion and the Rhaetian deposits are commonly truncated at the top (Pieńkowski, 2004; Pieńkowski et al., 2012, 2014). This part of the Zagaje Formation usually commences with a sandstone layer resting on the sequence boundary followed by interstratified claystones, mudstones and sandstones (Pieńkowski, 2004; Brański, 2011a).

During the Rhaetian-earliest Hettangian, continental alluvial-lacustrine sedimentation prevailed in the area of Poland. Initially, a semi-dry inland basin of playa character prevailed, where deposits of the Wielichowo Beds accumulated (Pieńkowski et al., 2012). The subsequent alluvial and lacustrine deposits are assigned to the same lithostratigraphic unit, the Zagaje Formation (Pieńkowski, 2004; Pieńkowski et al., 2012), because the earliest Hettangian alluvial deposition was a continuation of the Rhaetian one. The environments were dominated by meandering and anastomosing river systems and were gradually transforming into wetlands (Pieńkowski, 2004; Brański, 2011a). Fine-grained sediments were formed mainly in overbank environments (distal floodplain, shallow overgrowing lakes). After the hot, semi-dry climate that dominated in the Norian, the Early-Middle Rhaetian seems to have been characterized by seasonal precipitation. The Late Rhaetian-Early Hettangian climate were generally much wetter than in the Early-Middle Rhaetian, although it seems that drier periods still occurred (Pieńkowski et al., 2012).

\section{MATERIALS AND METHODS}

In order to infer the Rhaetian-earliest Hettangian palaeoclimatic events, a set of 87 samples was taken from four borehole cores (Kamień Pomorski IG 1, Kaszewy 1, Niekłań PIG-1 and Huta OP-1) to analyse the bulk rock mineralogy, clay mineralogy and major element geochemistry. In the first two cases, the sections analysed represent almost exclusively the Rhaetian, in the third the Rhaetian and lowermost Hettangian, and in fourth the lowermost Hettangian only. Most of the samples collected comprise claystones and mudstones from the Zagaje Formation in various parts of the MPT: the Pomeranian segment, the Kuyavian segment, and the Holy Cross Mountains segment (Fig. 2). The Kaszewy borehole section provides the preliminary results only because this section is still being studied. As already mentioned, the Rhaetian deposits are commonly truncated at the top by erosion. Most probably, the erosion in Kamien Pomorski was insignificant owing to the local tectonic regime (Pieńkowski et al., 2012). In the Kaszewy and Niekłań sections, the hiatus at the Triassic-Jurassic boundary partially embraces Late Rhaetian; however, it is hard to determine how much of the Late Rhaetian succession was removed by erosion. In the Huta borehole section, the Rhaetian is most likely lacking and the Norian mudstones are overlain directly by the lowermost Hettangian deposits, because the first Jurassic sequence boundary merged with the lower sequence boundaries between Middle and Upper Rhaetian and between Rhaetian and Norian deposits.

All samples were studied at the Polish Geological Institute National Research Institute laboratories. Each rock sample were coarsely crushed in a Fritsch crusher, dried at a temperature of $110^{\circ} \mathrm{C}$, and ground to obtain a fine, homogeneous powder of the bulk rock with particles $<63 \mu \mathrm{m}$. Bulk rock compositions and clay minerals were identified by X-ray diffraction (XRD) using a Phillips PW 3020 X'Pert diffractometer with CuK $\alpha$ radiation. The bulk-rock mineralogy was determined on XRD patterns of powder samples. The ICDD (International Centre for Diffraction Data) database was used for qualitative determination of minerals. The Reference Intensity Ratio method, embedded in control software, was applied to semi-quantitative phase analysis. Clay minerals were identified by XRD on oriented mounts of non-calcareous clay-sized particles, separated from suspension by differential settling according to Stoke's Law. Upper Rhaetian-Hettangian claystones and mudstones from the epicontinental basin of Poland are commonly non-calcareous and decalcification is not necessary. The calcareous samples were treated with $10 \%$ acetic acid for removal of carbonates. Oriented specimens were prepared by smearing a paste of the $<2 \mu \mathrm{m}$ fraction onto a glass slide. For each sample, three X-ray analyses were performed: after air-drying, ethylene-glycol solvation, and heating at $550^{\circ} \mathrm{C}$. The individual clay minerals were identified using the position of the (001) series of basal reflections on the three X-ray diagrams (Moore and Reynolds, 1997; Środoń, 2006). Kaolinite was identified using the reflection at $\sim 7 \AA$, illite at $\sim 10 \AA$ and chlorite at $\sim 14 \AA$ (on the basis of X-ray diagrams of air-dried and heated specimens; Fig. 3). Additionally, the kaolinite-chlorite doublet at $3.5 \AA$ was used to asses the proportion of these minerals. A slight deflection at $7 \AA$ that is typical of berthierine was also observed in several samples (Fig. $3 C$ ). Smectite and the rarely and locally observed illite-smectite mixed-layers (mostly with $>90 \%$ illite content) were here determined on $15-17 \AA$ and 11-13 $\AA$ peaks, respectively. Semi-quantitative estimations of clay mineral contents were based on the peak areas of basal reflections summed to $100 \%$. Illite-smectite mixed-layers were included in illite. SEM observations of selected samples were also performed using a LEO 1430 scanning electron microscope with an energy dispersive spectrometer (EDS Oxford Instrument; Fig. 4).

Geochemical analyses of major elements and organic matter were performed on bulk rock samples. After melting of samples in a Pt-Au melting-pot (at a temperature of $1000^{\circ} \mathrm{C}$ ), major elements were measured by X-ray fluorescence using a Phillips $P W 2400$ spectrometer in accordance with accredited research procedure. The lower detection limits of the individual components ranged from 0.001 to $0.1 \%$ (for the most part, $0.01 \%$ ). Total organic carbon (TOC) content was established by the coulometric method. 

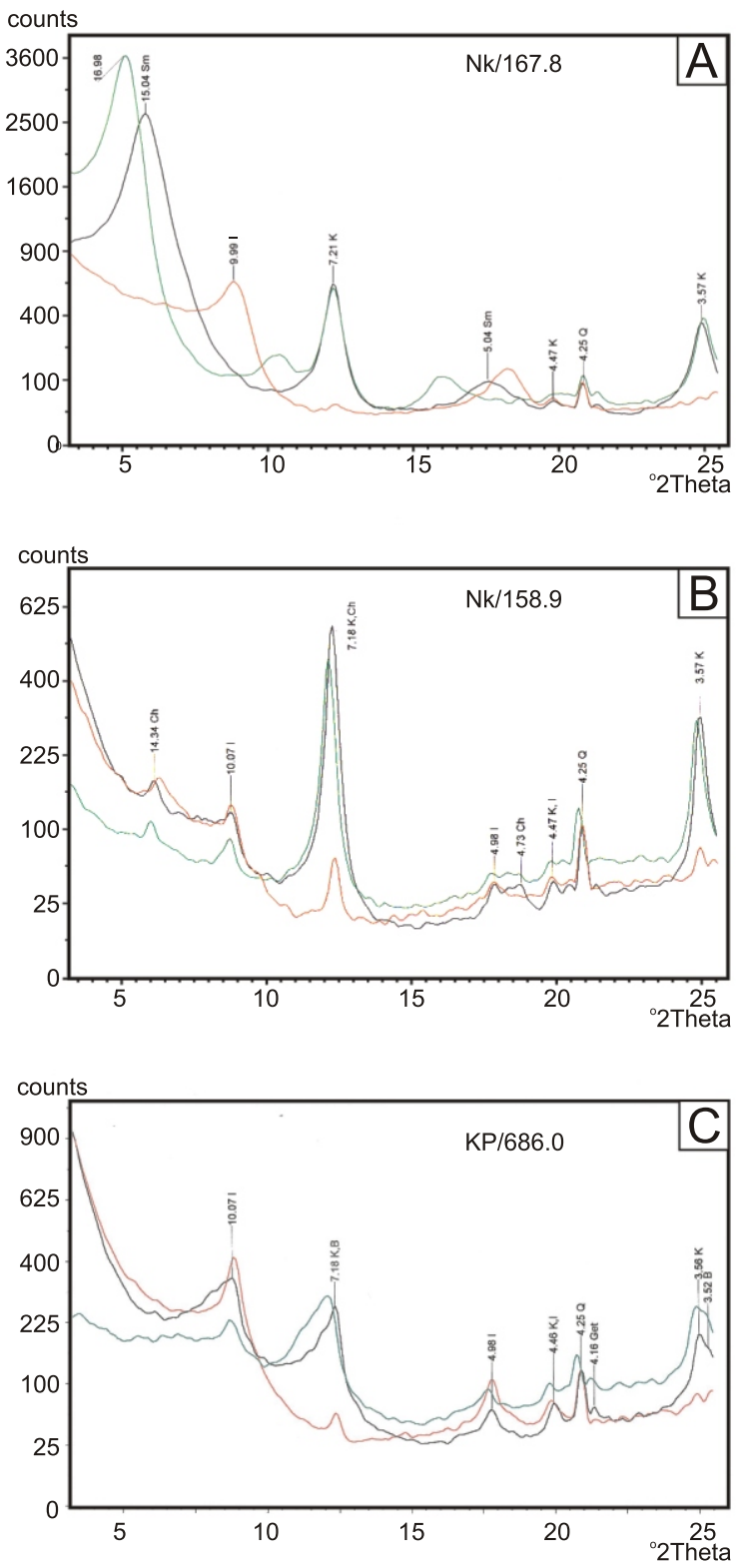

Fig. 3. Examples of X-ray diagrams of selected samples ( $<2 \mu \mathrm{m}$ fraction) from the Triassic-Jurassic boundary interval (carried out by W. Narkiewicz)

A - smectite-dominated claystone with accompanying kaolinite (Rhaetian, Wielichowo Beds, Niekłań PIG-1 borehole, depth $167.8 \mathrm{~m})$; B - kaolinite-dominated claystone with subordinate illite and chlorite (lowermost Hettangian, Zagaje Formation, Niekłań PIG-1 borehole, depth $158.9 \mathrm{~m})$; C - kaolinite, berthierine and illite in claystone (Rhaetian, Zagaje Formation, Kamień Pomorski IG 1 borehole, depth $686.0 \mathrm{~m}$ ); black line - air-dried sample, green line glycolated sample, red line - heated sample $\left(550^{\circ} \mathrm{C}\right)$; clay mineral content was determined on the peak areas of characteristic basal reflections $(B-$ berthierine $\sim 7 \AA, \mathrm{Ch}-$ chlorite $\sim 14 \AA$, I - illite $\sim 10 \AA$, $\mathrm{K}$ - kaolinite $\sim 7 \AA$, Sm - smectite 15-17 $\AA$ )

For each bulk rock sample, a "clay index" $(\mathrm{Cl})$ was calculated on X-ray diffraction percentage values using the formula: clay index $(\mathrm{Cl})=$ clay minerals $(\mathrm{CM}) /$ [quartz $(\mathrm{Q})+$ feldspar $(\mathrm{F})$ ]. Moreover, various indices reflecting the degree of silicate weathering using the clay mineral composition of samples were calculated. The kaolinite/illite (K/I), kaolinite/illite+chlorite $(\mathrm{K} / \mathrm{I}+\mathrm{Ch})$, and kaolinite/smectite $(\mathrm{K} / \mathrm{Sm})$ proportions are expressed by ratios of the main diffraction peak intensities of these minerals. Next, the following chemical indices were determined using major element concentrations: $\mathrm{Al} / \mathrm{K}$ ratio, Chemical Index of Alternation - CIA (Nesbitt and Young, 1982) and CIA* (Goldberg and Humayun, 2010), Chemical Index of Weathering - CIW (Harnois, 1988), Plagioclase Index of Weathering - PIA (Fedo et al., 1995), Index of Compositional Variability - ICV (Cox et al., 1995) and Al/Ti ratio. The indices are defined as follows:

$\mathrm{CIA}=\left[\mathrm{Al}_{2} \mathrm{O}_{3} /\left(\mathrm{Al}_{2} \mathrm{O}_{3}+\mathrm{CaO} *+\mathrm{Na}_{2} \mathrm{O}+\mathrm{K} 2 \mathrm{O}\right)\right] \times 100$

$\mathrm{Cl}^{*}=\mathrm{Al}_{2} \mathrm{O}_{3} /\left(\mathrm{CaO}^{*}+\mathrm{Na}_{2} \mathrm{O}+\mathrm{K}_{2} \mathrm{O}\right)$;

$\mathrm{CIW}=\left[\mathrm{Al}_{2} \mathrm{O}_{3} /\left(\mathrm{Al}_{2} \mathrm{O}_{3}+\mathrm{CaO}^{*}+\mathrm{Na}_{2} \mathrm{O}\right] \times 100\right.$

$\mathrm{PIA}=\left\{\left(\mathrm{Al}_{2} \mathrm{O}_{3}-\mathrm{K}_{2} \mathrm{O}\right) /\left[\left(\mathrm{Al}_{2} \mathrm{O}_{3}-\mathrm{K}_{2} \mathrm{O}\right)+\mathrm{CaO}^{*}+\mathrm{Na}_{2} \mathrm{O}\right]\right\} \times 100$;

$\mathrm{ICV}=\left(\mathrm{Fe}_{2} \mathrm{O}_{3}+\mathrm{K}_{2} \mathrm{O}+\mathrm{Na}_{2} \mathrm{O}+\mathrm{CaO}+\mathrm{MgO}+\mathrm{MnO}+\right.$ $\left.\mathrm{TiO}_{2}\right) / \mathrm{Al}_{2} \mathrm{O}_{3}$.

For calculation of chemical indices (excepting ICV and $\mathrm{Al} / \mathrm{Ti}$ ), raw abundances of individual elements were converted into moles by dividing the weight percent by molecular weight (Retallack, 2001; Sheldon and Tabor, 2009). CaO* represents the $\mathrm{Ca}$ content in the silicate fraction only. According to McLennan (1993), if the CaO molar content is less than that of $\mathrm{Na}_{2} \mathrm{O}$, the $\mathrm{CaO}$ content measured can be used for $\mathrm{CaO}^{*}$; when the $\mathrm{CaO}$ molar content is greater than that of $\mathrm{Na}_{2} \mathrm{O}, \mathrm{CaO}^{*}$ it is assumed to be equivalent to $\mathrm{Na}_{2} \mathrm{O}$. Generally, the values of weathering indices increase with removal of mobile cations relative to stable residual components due to the growing intensity of weathering (Nesbitt and Young, 1982; Harnois, 1988; Fedo et al., 1995; Goldberg and Humayun, 2010) that is usually linked to climate conditions in the provenance areas. For example, the CIA (the most widely applied of weathering indices) increases from approximately 50 for unaltered feldspar to $70-85$ for illite and smectite, and almost 100 for kaolinite, chlorite and gibbsite (Nesbitt and Young, 1982; Fedo et al., 1995). Fresh rocks and minerals may have CIA values even lower than 50 . The average upper crust has a CIA value about 47 (Mc Lennan, 1993). Moreover, the bulk rock Al/Ti ratio may be used as a preliminary indicator of the source rocks. Low values suggest mafic or ultramafic rocks and high values indicate felsic source (Nesbitt, 1979; Hayashi et al., 1997).

Finally, most of the new mineralogical and geochemical data was plotted along with the lithology, facies succession, and sequence stratigraphy established by Pieńkowski (2004; Pieńkowski et al., 2012) for the all the borehole sections studied (Figs. 5-8). In the Kamień Pomorski section (Fig. 5), they were also compared to existing isotope data reported by Pieńkowski et al. (2012).

\section{RESULTS}

Important bulk rock data (general mineralogical composition, $\mathrm{Cl}$, TOC content, $\mathrm{CIA}, \mathrm{ClA}^{*}$, CIW, PIA, ICV Al/K and $\mathrm{Al} / \mathrm{Ti}$ values) as well as clay fraction data (clay mineral compositions, $\mathrm{K} / \mathrm{I}$ and $\mathrm{K} / \mathrm{I}+\mathrm{Ch}$ and $\mathrm{K} / \mathrm{S} m$ values) of the Wielichowo Beds and Zagaje Formation are shown in Tables 2-4. Most of these are also depicted on Figures 5-8. Average data have been estimated for each core. Selected X-ray diagrams and the examples of SEM images are shown in Figures 3 and 4, respectively.

\section{BULK ROCK MINERALOGY}

The bulk rock samples of claystone and mudstone from the Rhaetian and Lower Hettangian examined are mainly com- 

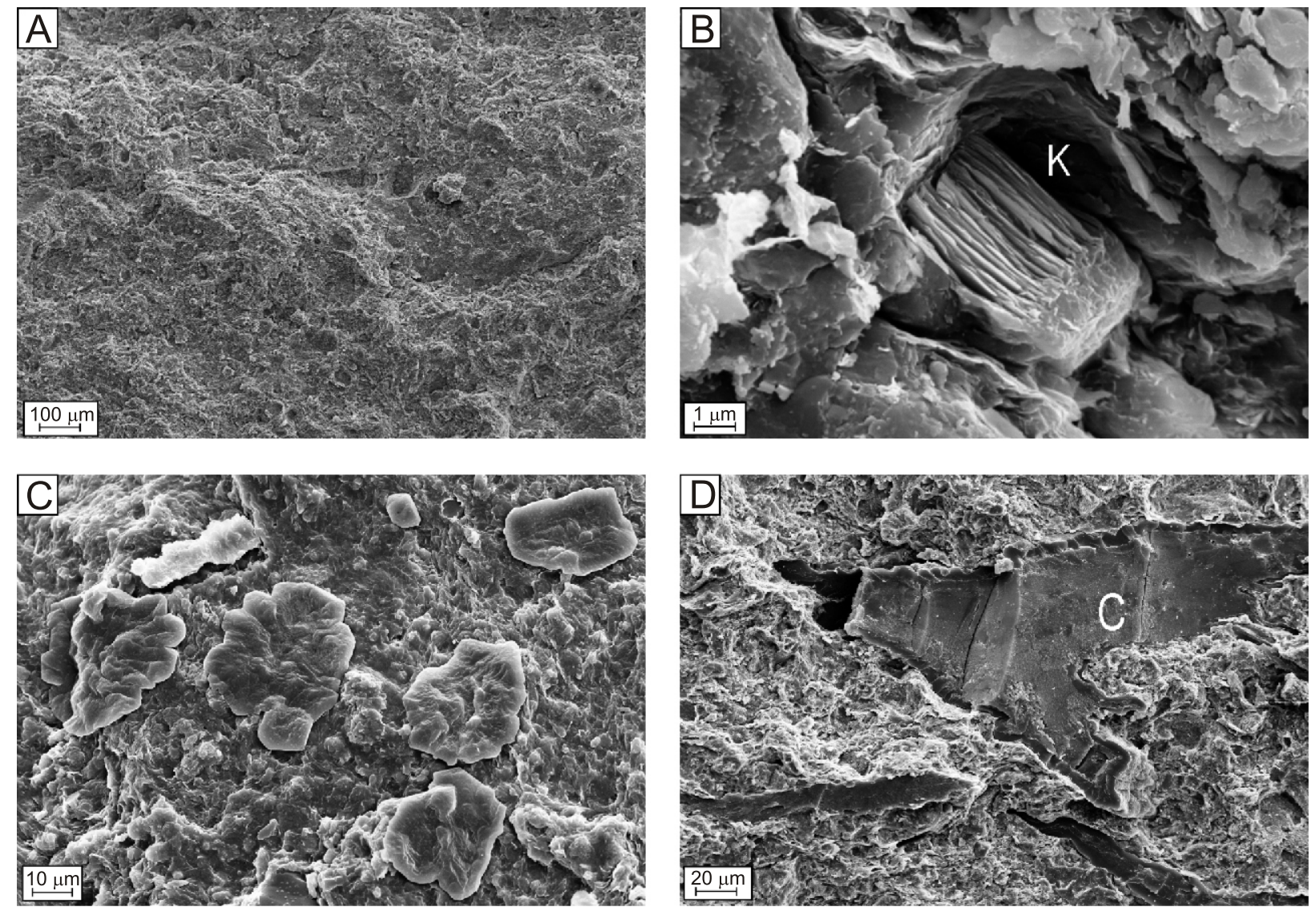

Fig. 4. Selected SEM images (carried out by L. Giro)

A - typical Rhaetian claystone dominated by detrital kaolinite-smectite matrix (Niekłań PIG-1 borehole, depth 166.4 m); B - subordinate authigenic kaolinite $(\mathrm{K})$ surrounded by a detrital kaolinite-illite matrix (lowermost Hettangian, Zagaje Fm., Huta OP-1 borehole, depth $183.5 \mathrm{~m})$; C - Fine pieces of disintegrated calcrete and silcrete eroded from Norian palaeosols and dispersed in kaolinitic clay (Upper Rhaetian, Zagaje Fm. Niekłań PIG-1 borehole, depth $164.3 \mathrm{~m}$ ); D - Organic carbon (C) in detrital kaolinite-illite matrix (lowermost Hettangian, Zagaje Fm., Niekłań PIG-1 borehole, depth 157.7 m)

KAMIEŃ POMORSKI IG 1

b u I k r o c k d a t a $\quad<0.002 \mathrm{~mm}$ fraction chemical indices clay minerals

simplified

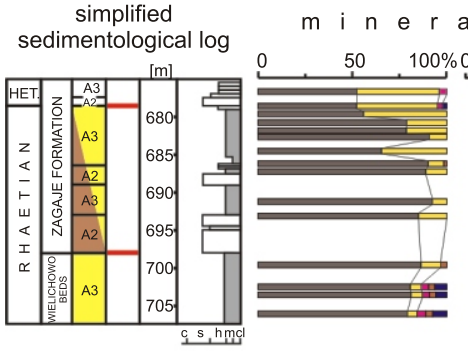

Facies associations
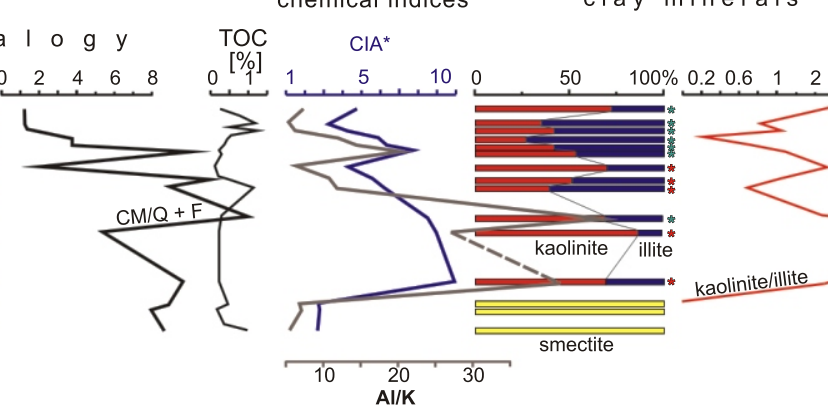

A2 sandstones and mudstones of meandering,

A2 anastomosing channels and floodplains

A3 mudstones and claystones of lakes and distal floodplains

A4 coaly mudstones and claystones of swamps

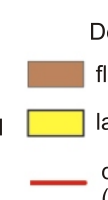

Depositional systems

fluvial (alluvial)

lacustrine

depositional sequence boundaries

Lithology

c s $\mathrm{hmcl}$

$\mathrm{cl}$ - claystone

$\mathrm{m}$ - mudstone

$\mathrm{h}$ - heteroliths (after Pieńkowski, 2004; Pieńkowski et al., 2012) $\mathrm{c}$ - - conglonemerate

isotope data

${ }^{187} \mathrm{Os} /{ }^{186} \mathrm{Os} \quad \delta^{13} \mathrm{C}_{\text {wood }}(\%$ VPDB $)$

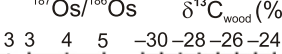

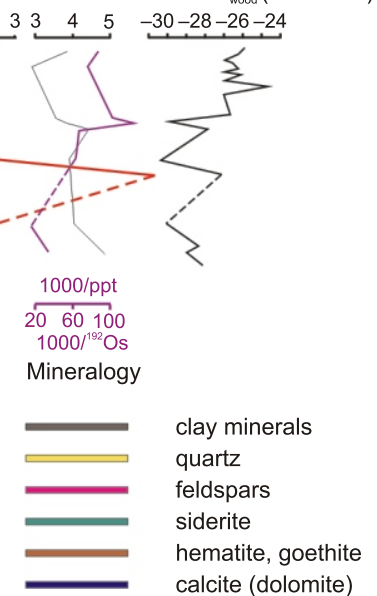




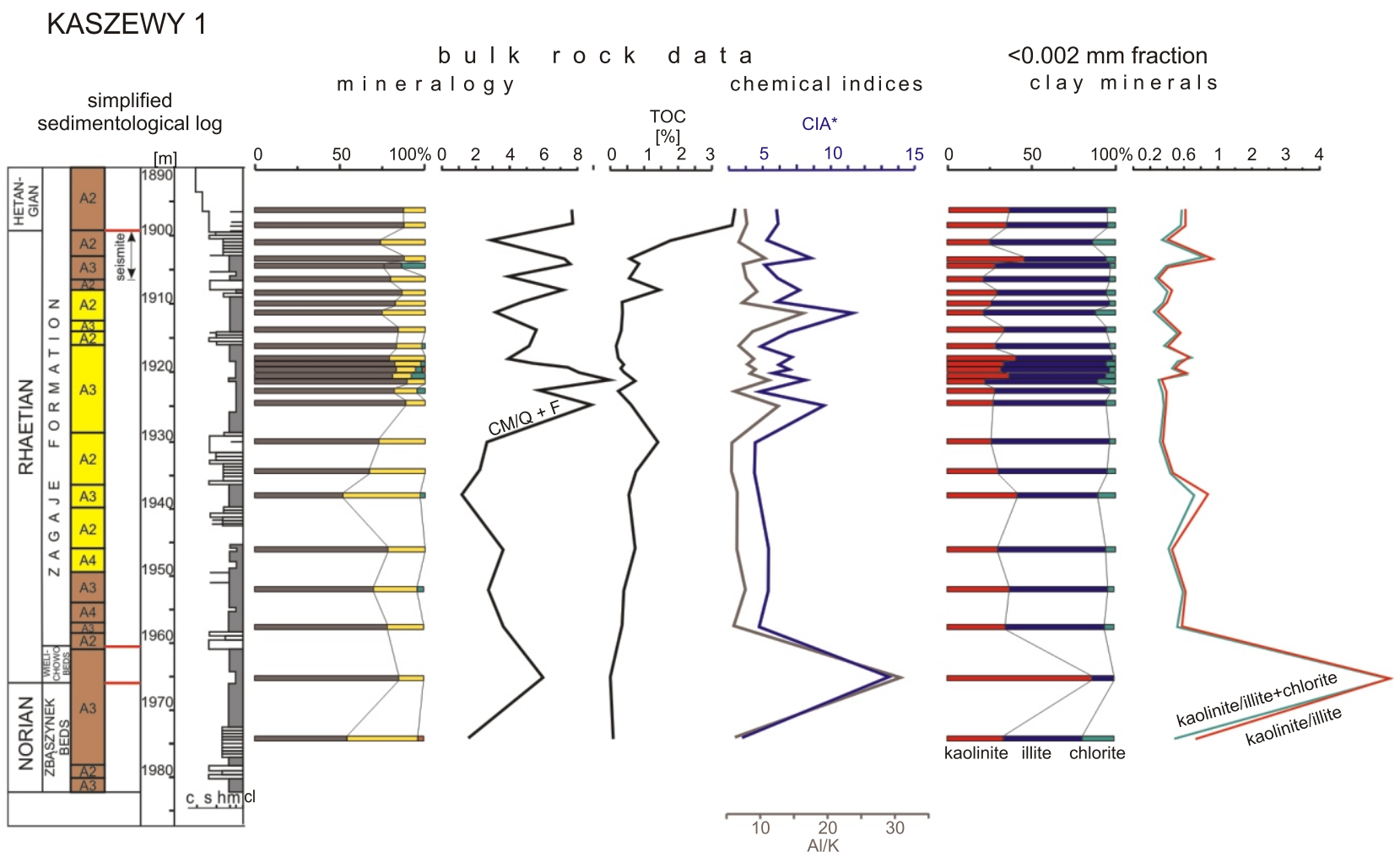

Fig. 6. Bulk rock and $<2 \mu \mathrm{m}$ fraction data from the Kaszewy 1 borehole plotted against a simplified sedimentological log

Clay index $(\mathrm{Cl}=\mathrm{CM} / \mathrm{Q}+\mathrm{F})$ spikes seem to be consistent with sedimentary cycles; TOC content clearly increases at the beginning of the Hettangian; note the prominent kaolinite peak in the Wielichowo Beds that correlates with the highest values of chemical indices; in the Zagaje Formation, the kaolinite content and values of the weathering indices are relatively low, probably because of a moderate diagenetic overprint (illitisation); for the same reason the fluctuations in clay mineral ratios and of chemical indices are less distinct; all bulk rock and clay mineral data (including TOC content) are from this study; for explanations see Figure 5

posed of phyllosilicates (51-91\%, average of 70-85\% depending on the borehole studied and lithostratigraphic unit; Tables $2-4)$. Quartz is less abundant but occurs in varied amounts $(7-45 \%$, average of $10-26 \%)$. The clay index $(\mathrm{Cl})$ of samples varies from 1.1 to 13.0 (with an average of 2.7-8.7; Tables $2-4$ ), according to their position within sedimentary cycles; almost all samples are represented by claystones or clayey mudstones. In the Lower-Middle Rhaetian Wielichowo Beds, hematite, goethite, feldspars, calcite and locally dolomite are observed with proportions of $0-8 \%$, but siderite is absent (Table 2). The content of organic matter is very low and TOC value does not exceed $0.42 \%$. In the bulk rock samples of claystones and mudstones examined from the Zagaje Fm. (Upper Rhaetian-Lower Hettangian) siderite is observed with proportions of $0-8 \%$ (to as much as $24 \%$ ). Other minerals (feldspars, hematite and goethite) appear sporadically and mostly in accessory amounts (Tables 3 and 4 ). Calcite and dolomite are ab- sent. The distribution of organic matter is variable and the total organic carbon (TOC) content ranges from 0.14 to $4.20 \%$ (Tables 3 and 4). The abundance of organic carbon is distinctly higher in the Lower Hettangian than in the Rhaetian.

\section{BULK ROCK CHEMISTRY - WEATHERING INDICES}

The major element geochemistry and the values of chemical indices generally reflect bulk rock mineralogy and clay mineral composition. They are very diverse in the Lower-Middle Rhaetian Wielichowo Beds and generally high in the Upper Rhaetian-Lower Hettangian Zagaje Fm. The CIA values fluctuate extremely (with limits of 63.2-92.6) in the Wielichowo Beds (Table 2). In the Zagaje Formation the CIA varies from 78.7 to 95.6, but in the vast majority of cases it exceeds 85 , corresponding to residual clays with a high kaolinite content (Nesbitt and Young, 1982). Average CIA values in the Zagaje Formation

Fig. 5. Bulk rock and $<2 \mu \mathrm{m}$ fraction data from the Kamień Pomorski IG 1 borehole plotted against a simplified sedimentological log

In the topmost part of the Wielichowo Beds a crucial shift in clay mineral assemblage is shown; note that the first kaolinite enrichment coincides with the "precursor" negative CIE ( 699.3 m) but the next kaolinite peak ( 692.9 m) slightly precedes the onset of the "initial" negative CIE ( $691.0 \mathrm{~m})$; note also distinct reversals of the kaolinite-illite ratio in the Zagaje Formation; in the topmost Rhaetian the kaolinite content diminishes (concordantly with the CIE positive shift) and rises again in the lowermost Hettangian; red asterisk - berthierine presence, green asterisk - serpentine presence (close to clay mineral bands); all simplified sedimentological logs (Figs. 6-9) are mostly adapted from Pieńkowski (2004) and Pieńkowski et al. (2012); carbon-isotope curve and Os-isotope curves after Pieńkowski et al. (2012); TOC content in the Kamień section adapted from Marynowski and Simoneit (2009); other bulk rock data (mineralogy and selected chemical indices) and clay mineralogical data (clay mineral composition, kaolinite/illite ratio) are from this study; other explanations are included in the text 


\section{NIEKŁAŃ PIG-1}

simplified

sedimentological log

b u I k r o c k d a t a

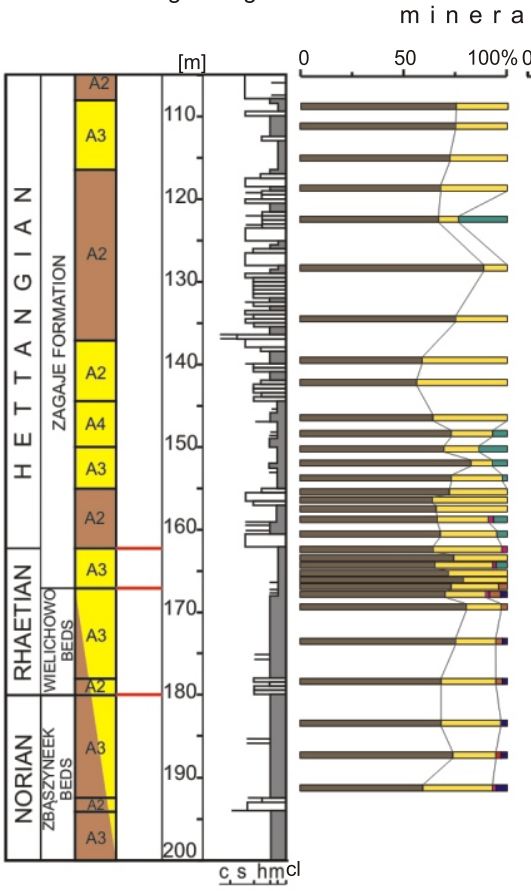

chemical indices

$\mathrm{ClA}^{*}$
$<0.002 \mathrm{~mm}$ fraction

clay minerals
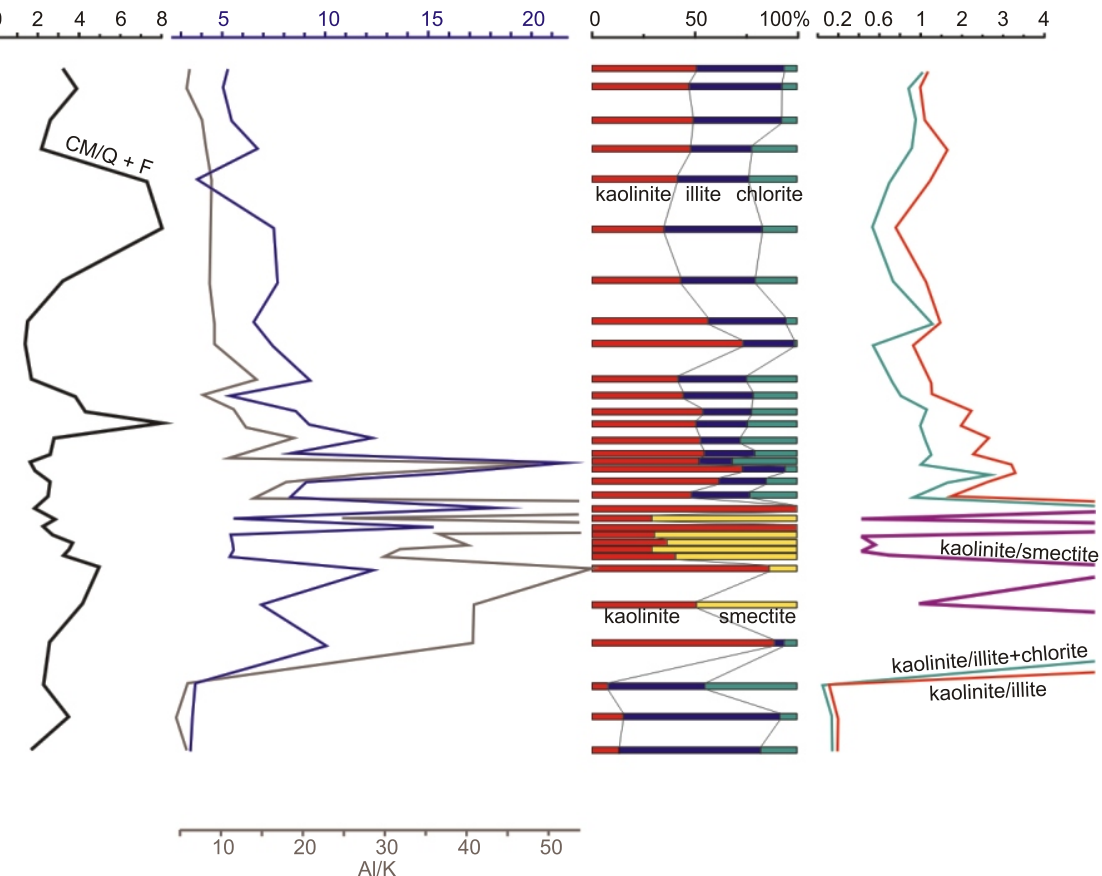

Fig. 7. Bulk rock and $<2 \mu \mathrm{m}$ fraction data from the Niekłań PIG-1 borehole plotted against a simplified sedimentological log

Note the series of frequent and drastic changes in the clay mineral composition and weathering indices values that correspond to inferred catastrophic climate reversals in Rhaetian-earliest Hettangian time; all bulk rock and clay minerals data are from this study; for explanations see Figure 5
HUTA OP-1
b u I k r o c k d a t a

simplified sedimentological log m in e r a l o g y $\quad$ TOC
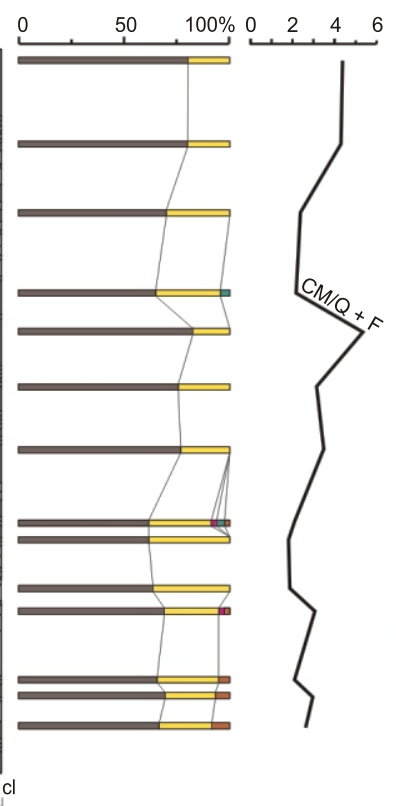

chemical indices
$\mathrm{CIA}^{*}$

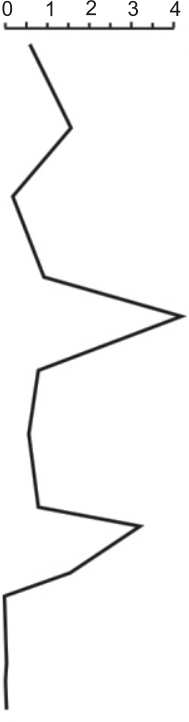

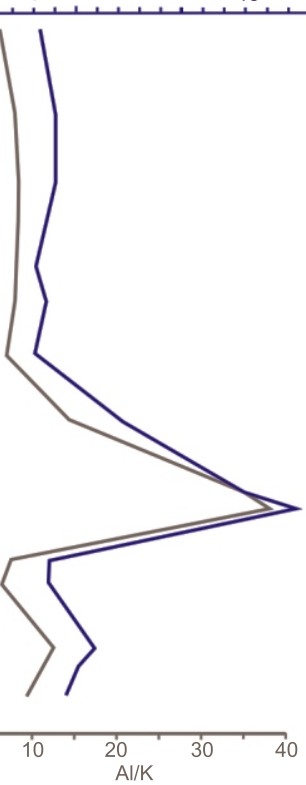

$<0.002 \mathrm{~mm}$ fraction clay minerals $\begin{array}{lllllllll}0 & 50 & 100 \% & 0.2 & 0.6 & 1 & 2 & 3 & 4\end{array}$

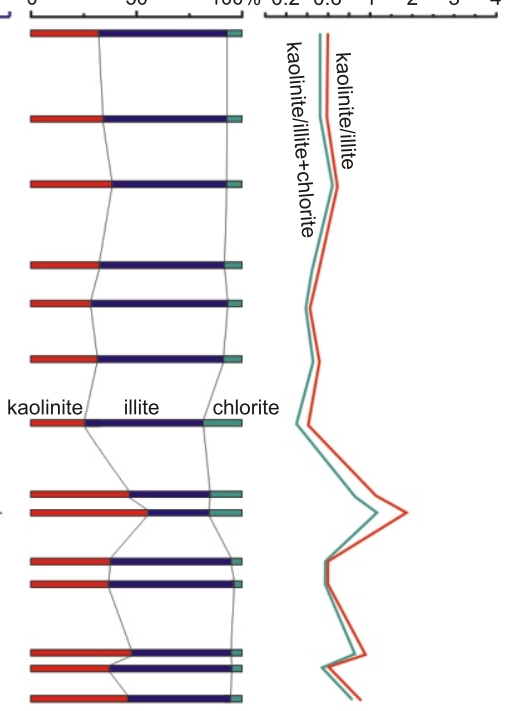

Fig. 8. Bulk rock and $<2 \mu \mathrm{m}$ fraction data from the Huta OP-1 borehole plotted against a simplified sedimentological log

Note the spikes on TOC content curve and major kaolinite peak in the lowermost Hettangian that correlates with highest values of chemical indices (as in the Niekłań PIG-1 borehole section); note also that the hiatus spans most probably the whole Rhaetian; all bulk rock and clay minerals data are from this study; for explanations see Figure 5 
Ta ble 2

Bulk rock and $<2 \mu \mathrm{m}$ fraction data from the Wielichowo Beds (Lower-Middle Rhaetian) in the boreholes sampled

\begin{tabular}{|c|c|c|c|c|c|}
\hline \multirow{2}{*}{\multicolumn{2}{|c|}{ Components, indices }} & \multicolumn{4}{|c|}{ Borehole } \\
\hline & & \multirow{2}{*}{$\begin{array}{c}\text { KAMIEŃ } \\
\text { POMORSKI IG } 1 \\
77-85(\mathbf{8 0})\end{array}$} & \multirow{2}{*}{$\frac{{ }^{*} \text { KASZEWY } 1}{85}$} & \multirow{2}{*}{\begin{tabular}{|c|} 
NIEKŁAŃ PIG-1 \\
$68-80(73)$ \\
\end{tabular}} & HUTA OP-1 \\
\hline \multirow{6}{*}{ Bulk rock mineralogy } & clay minerals CM [\%] & & & & \multirow{19}{*}{ hiatus } \\
\hline & quartz + feldspar Q + F [\%] & $9-10(10)$ & 14 & $16-26(21)$ & \\
\hline & goethite, hematite [\%] & $3-4(4)$ & 0 & $3-6(4)$ & \\
\hline & calcite, dolomite [\%] & $0-8(5)$ & 0 & $0-3(1)$ & \\
\hline & $\mathrm{Cl}=\mathrm{CM} / \mathrm{Q}+\mathrm{F}$ & $7.9-9.4(8.7)$ & 6.1 & $2.6-5.0(3.7)$ & \\
\hline & TOC [\%] & $0.18-0.42(\mathbf{0 . 2 8})$ & $<0.10$ & - & \\
\hline \multirow{6}{*}{$\begin{array}{l}\text { Clay minerals } \\
(<2 \mu \mathrm{m} \text { fraction })\end{array}$} & kaolinite K [\%] & $0-69(17)$ & 86 & $30-90(60)$ & \\
\hline & illite I [\%] & $0-31(8)$ & 14 & $0-5(1)$ & \\
\hline & chlorite Ch [\%] & 0 & 0 & $0-5(1)$ & \\
\hline & smectite Sm [\%] & $0-100(75)$ & 0 & $0-70(38)$ & \\
\hline & $\mathrm{K} / \mathrm{I}$ & $0.0-2.2(\mathbf{0 . 6})$ & 6.1 & - & \\
\hline & $\mathrm{K} / \mathrm{I}+\mathrm{Ch}$ & $0.0-2.2(\mathbf{0 . 6})$ & 6.1 & - & \\
\hline \multirow{7}{*}{$\begin{array}{l}\text { Chemical indices } \\
\text { (bulk rock sample) }\end{array}$} & $\mathrm{Al} / \mathrm{K}$ & $5.3-41.5(\mathbf{1 5 . 2})$ & 30.7 & $29.7-55.8(39.7)$ & \\
\hline & $\mathrm{CIA}$ & $63.2-90.9(\mathbf{7 0 . 5})$ & 92.6 & $84.8-92.5$ (88.2) & \\
\hline & $\mathrm{ClA}^{*}$ & $1.7-10.0(3.8)$ & 12.6 & $5.6-12.4(10.2)$ & \\
\hline & CIW & $69.7-92.9(76.3)$ & 95.5 & $87.3-94.1(90.3)$ & \\
\hline & PIA & $66.3-92.8(73.9)$ & 95.4 & $86.9-94.0(\mathbf{9 0 . 0})$ & \\
\hline & ICV & $0.45-2.08(1.53)$ & 0.24 & $0.46-0.77(\mathbf{0 . 6 0})$ & \\
\hline & $\mathrm{Al} / \mathrm{Ti}$ & $18-28(22)$ & 31 & $11-30(23)$ & \\
\hline
\end{tabular}

The average values are given in parentheses (bold font); other explanations are in the text; * - only single sample

Table 3

Bulk rock and $<2 \mu \mathrm{m}$ fraction data from the Zagaje Formation (Upper Rhaetian part) in the boreholes sampled

\begin{tabular}{|c|c|c|c|c|c|}
\hline \multirow{2}{*}{\multicolumn{2}{|c|}{ Components, indices }} & \multicolumn{4}{|c|}{ Borehole } \\
\hline & & \multirow{2}{*}{$\begin{array}{c}\begin{array}{c}\text { KAMIEŃ } \\
\text { POMORSKI IG } 1\end{array} \\
51-91(76) \\
\end{array}$} & \multirow{2}{*}{$\begin{array}{c}\text { KASZEWY } 1 \\
52-90(\mathbf{7 8}) \\
\end{array}$} & \multirow{2}{*}{$\begin{array}{c}\text { NIEKŁAŃ PIG-1 } \\
64-78(\mathbf{7 1}) \\
\end{array}$} & HUTA OP-1 \\
\hline \multirow{6}{*}{ Bulk rock mineralogy } & clay minerals CM [\%] & & & & \multirow{19}{*}{ hiatus } \\
\hline & quartz + feldspar Q + F [\%] & $7-45(23)$ & $9-45(18)$ & $21-35(28)$ & \\
\hline & siderite $[\%]$ & 0 & $0-8(2)$ & $0-5(1)$ & \\
\hline & others [\%] & $0-2(<1)$ & $0-2(<1)$ & 0 & \\
\hline & $\mathrm{Cl}=\mathrm{CM} / \mathrm{Q}+\mathrm{F}$ & $1.1-13.0(5.9)$ & $1.2-10.0(5.2)$ & $1.8-3.7(2.7)$ & \\
\hline & TOC [\%] & $0.10-1.25(\mathbf{0 . 5 1})$ & $0.23-1.78(\mathbf{0 . 6 5 )}$ & - & \\
\hline \multirow{6}{*}{$\begin{array}{l}\text { Clay minerals } \\
(<2 \mu \mathrm{m} \text { fraction })\end{array}$} & kaolinite K [\%] & $16-86(52)$ & $21-45(31)$ & $31-100(60)$ & \\
\hline & illite I [\%] & $14-84(48)$ & $48-75(63)$ & 0 & \\
\hline & chlorite Ch [\%] & 0 & $1-14(6)$ & 0 & \\
\hline & smectite Sm [\%] & 0 & 0 & $0-70(40)$ & \\
\hline & $\mathrm{K} / \mathrm{I}$ & $0.2-6.1(\mathbf{1 . 6})$ & $0.3-0.9(\mathbf{0 . 5})$ & - & \\
\hline & $\mathrm{K} / \mathrm{I}+\mathrm{Ch}$ & $0.2-6.1(\mathbf{1 . 6})$ & $0.3-0.8(\mathbf{0 . 4})$ & - & \\
\hline \multirow{7}{*}{$\begin{array}{l}\text { Chemical indices } \\
\text { (bulk rock sample) }\end{array}$} & $\mathrm{Al} / \mathrm{K}$ & $5.3-45.3(15.9)$ & $5.5-15.9(8,2)$ & $24.8-215.0(\mathbf{1 0 4 . 6})$ & \\
\hline & $\mathrm{ClA}$ & $78.7-90.0(85.1)$ & $82.2-91.2(85,5)$ & $83.3-95.6(\mathbf{8 8 . 6})$ & \\
\hline & $\mathrm{ClA}^{*}$ & $3.2-9.0(6.1)$ & $4.6-10.4(6.1)$ & 5.4-18.7 (10.1) & \\
\hline & CIW & 88.9-93.7 (92.1) & 94.6-97.1 (96.1) & $86.5-95.4(\mathbf{9 0 . 1})$ & \\
\hline & $\mathrm{PIA}$ & 86.7-92.9 (91.3) & 93.8-96.8 (95.6) & 86.2-95.4 (89.9) & \\
\hline & ICV & $0.28-0.83(\mathbf{0 . 4 2})$ & $0.27-1.05(\mathbf{0 . 4 4 )}$ & $0.21-0.73(\mathbf{0 . 5 0})$ & \\
\hline & $\mathrm{Al} / \mathrm{Ti}$ & 8-28 (18) & $14-36(22)$ & $12-17(15)$ & \\
\hline
\end{tabular}

Explanation as in the Table 2 
Bulk rock and $<2 \mu \mathrm{m}$ fraction data from the Zagaje Formation (Lower Hettangian part) in the boreholes sampled

\begin{tabular}{|c|c|c|c|c|c|}
\hline \multirow{2}{*}{\multicolumn{2}{|c|}{ Components, indices }} & \multicolumn{4}{|c|}{ Borehole } \\
\hline & & \multirow{2}{*}{$\begin{array}{c}\text { *KAMIEŃ } \\
\text { POMORSKI IG } 1 \\
51\end{array}$} & \multirow{2}{*}{$\begin{array}{c}\text { KASZEWY } 1 \\
84-86(85) \\
\end{array}$} & \multirow{2}{*}{$\begin{array}{c}\text { NIEKŁAŃ PIG-1 } \\
56-88(70)\end{array}$} & \multirow{2}{*}{$\begin{array}{c}\text { HUTA OP-1 } \\
62-80(\mathbf{7 1})\end{array}$} \\
\hline \multirow{6}{*}{ Bulk rock mineralogy } & clay minerals CM [\%] & & & & \\
\hline & $\begin{array}{c}\text { quartz + feldspar Q + F } \\
{[\%]}\end{array}$ & 47 & $10-12(11)$ & $9-43(25)$ & $15-34(26)$ \\
\hline & siderite [\%] & 0 & 0 & $0-24(4)$ & $0-4(1)$ \\
\hline & others [\%] & $<1$ & 0 & 0 & $0-2(<1)$ \\
\hline & $\mathrm{Cl}=\mathrm{CM} / \mathrm{Q}+\mathrm{F}$ & 1.1 & $7.0-8.6(7.8)$ & $1.3-8.2(3.4)$ & $1.8-5.3(3.1)$ \\
\hline & TOC [\%] & 0.28 & $3.63-3.69$ (3.66) & - & $0.14-3.28(1.45)$ \\
\hline \multirow{6}{*}{$\begin{array}{l}\text { Clay minerals } \\
(<2 \mu \mathrm{m} \text { fraction })\end{array}$} & kaolinite K [\% & 71 & $34-37(36)$ & $35-73(\mathbf{5 0})$ & $25-55(37)$ \\
\hline & illite I [\%] & 29 & $57-59(58)$ & $16-48(32)$ & $29-65(53)$ \\
\hline & chlorite Ch [\%] & 0 & $6-7(6)$ & $5-32(18)$ & $5-19(10)$ \\
\hline & smectite Sm [\%] & 0 & 0 & 0 & 0 \\
\hline & $\mathrm{K} / \mathrm{I}$ & 2.4 & $0.6-0.7(\mathbf{0 . 6})$ & $0.7-3.3(1.8)$ & $0.4-1.9(\mathbf{0 . 8})$ \\
\hline & $\mathrm{K} / \mathrm{I}+\mathrm{Ch}$ & 2.4 & $0.5-0.6(\mathbf{0 . 5})$ & $0.5-2.7(1.1)$ & $0.3-1.2(\mathbf{0 . 6})$ \\
\hline \multirow{7}{*}{$\begin{array}{l}\text { Cchemical indices } \\
\text { (bulk rock sample) }\end{array}$} & $\mathrm{Al} / \mathrm{K}$ & 7.2 & $7.4-7.6(7.5)$ & $5.7-48.0(13.2)$ & $6.3-38.2(14.2)$ \\
\hline & $\mathrm{CIA}$ & 82.6 & $85.4-85.6(85.5)$ & $83.3-95.6(88.6)$ & $83.5-94.6(87.3)$ \\
\hline & $\mathrm{ClA}^{*}$ & 4.7 & $5.8-5.9(5.9)$ & $6.2-21.6(8.8)$ & $5.1-17.4(8.1)$ \\
\hline & CIW & 93.2 & 96.3-96.5 (96.4) & $95.4-98.4(97.1)$ & $93.8-97.6(95.9)$ \\
\hline & PIA & 92.7 & 95.8-96.0(95.9) & $94.9-98.1(96.8)$ & 92.9-97.1 (95.4) \\
\hline & ICV & 0.35 & $0.35-0.37(\mathbf{0 . 3 6})$ & $0.23-0.81(\mathbf{0 . 4 3})$ & $0.22-0.90(\mathbf{0 . 4 3})$ \\
\hline & $\mathrm{Al} / \mathrm{Ti}$ & 12 & $14-18(16)$ & $11-25(17)$ & $12-30(19)$ \\
\hline
\end{tabular}

Explanations as in the Table 2

mudrocks range with narrow limits, from 85.1 to 88.6 depending on the section studied (Tables 3 and 4). Average CIW and PIA values reach as much as 90.0-97.1, with the exception of the Wielichowo Beds samples from the Kamien section, which are strongly dominated by smectite (Tables 2-4). The highest values of CIA exceed 95, but maximum CIW and PIA values may be higher than 98 . Overall rock geochemistry is also shown in the A-CN-K diagrams (Fig. 9).

\section{CLAY MINERALS (<2 $\mu \mathrm{m}$ FRACTION)}

Clay mineralogical composition in the sections analysed is very diverse in the $<2 \mu \mathrm{m}$ fraction (Tables $2-4$ ), reflected by the $\mathrm{K} / \mathrm{I}, \mathrm{K} / \mathrm{I}+\mathrm{Ch}$ and in places the $\mathrm{K} / \mathrm{Sm}$ ratios (Figs. 5-8). In the earlier described Norian clays from Poland (Kozydra and Wyrwicki, 1977; Wiewióra and Wyrwicki, 1977; Brański, 2007b) illite predominates, accompanied by various but subsidiary amounts of illite-smectite mixed-layers, kaolinite, and chlorite. In the Norian Zbąszynek Beds studied in the Niekłań PIG-1 borehole (Fig. 7), illite (with subsidiary chlorite) also predominates and the kaolinite content is insignificant. In the Huta OP-1 borehole (Fig. 8), the clay mineral composition of presumed topmost Norian beds seems to be more atypical. The Kaszewy 1 borehole is still under study and the samples from Zbąszynek Beds have not yet been analysed.

In the Lower-Middle Rhaetian Wielichowo Beds the clay mineral assemblage is quite different. A high abundance of smectite is mostly observed (Fig. 3A), though the smectite type was not analysed. Accordingly to Kozydra and Wyrwicki (1977), smectites from the Upper Triassic in southern Poland are represented by beidellite with $\mathrm{Mg}$ and $\mathrm{Ca}$ in exchange positions or by beidellite-nontronite minerals. The kaolinite content is mostly moderate, although distinct kaolinite peaks already appear in this part of the succession (Figs. 5-7). Small amounts of illite and chlorite were detected only in some beds.

In the Zagaje Formation (Upper Rhaetian-Lower Hettangian) kaolinite and illite usually predominate, but the clay mineralogy of Rhaetian and Hettangian part of this lithostratigraphic unit is somewhat different. The clay mineral composition in the Rhaetian part of the Zagaje Formation is particularly diverse (Table 3). In general, a high content of kaolinite is observed here. Illite is also abundant in the Kamien and especially in the Kaszewy section (Figs. 5 and 6), but in Niekłań it is absent (Fig. 7). Only in Kaszewy is the clay fraction dominated by illite (with an average of $63 \%$ ) with subdominant amounts of kaolinite (with an average of 31\%). In Kamień and Niekłań the kaolinite predominates (with an average of $52 \%$ and $60 \%$, respectively; Table 3). Chlorite is still absent in both Kamien and Niekłań sections (Figs. 5 and 7), but is present in Kaszewy in small amounts (Fig. 6). In the lowest part of this formation in Niekłań, a significant smectite content (up to $70 \%$ ) is still observed (Fig. 7). On the other hand, in Kamień smectite is absent (Fig. 5), while the kaolinite phase is quite untypically accompanied by significant amounts of berthierine (Fig. 3C) and serpentine.

In the Lower Hettangian part of the Zagaje Formation the clay mineralogical composition is much more stable and consists of illite and kaolinite with significant amounts of subsidiary chlorite (Table 4; Figs. 7 and 8). In Niekłań, the clay fraction is still dominated by kaolinite (with an average of $50 \%$ ) with subdominant amounts of illite (average of $32 \%$ ). In Huta illite predominates (with an average of $53 \%$ ) by comparison with kaolinite (average of 37; Table 4). Smectite is almost absent and only some samples contain an insignificant illite-smectite mixed-layer admixture. 
A

KAMIEŃ POMORSKI IG 1

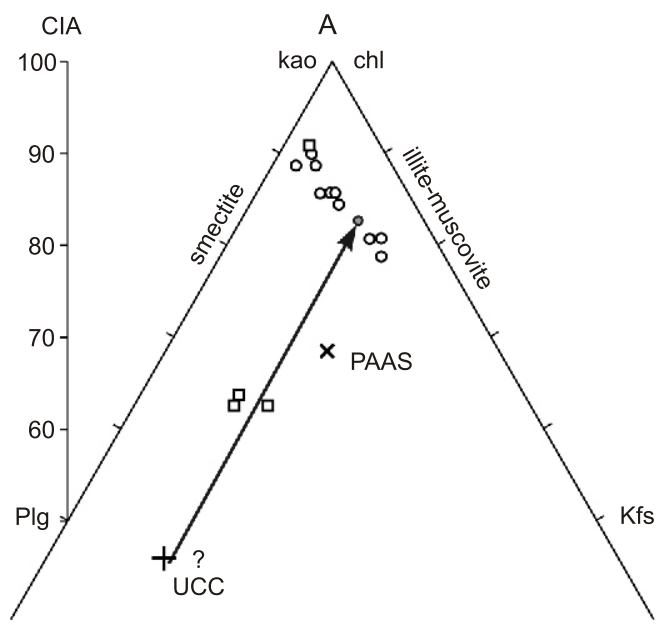

$\mathrm{CN}$
B

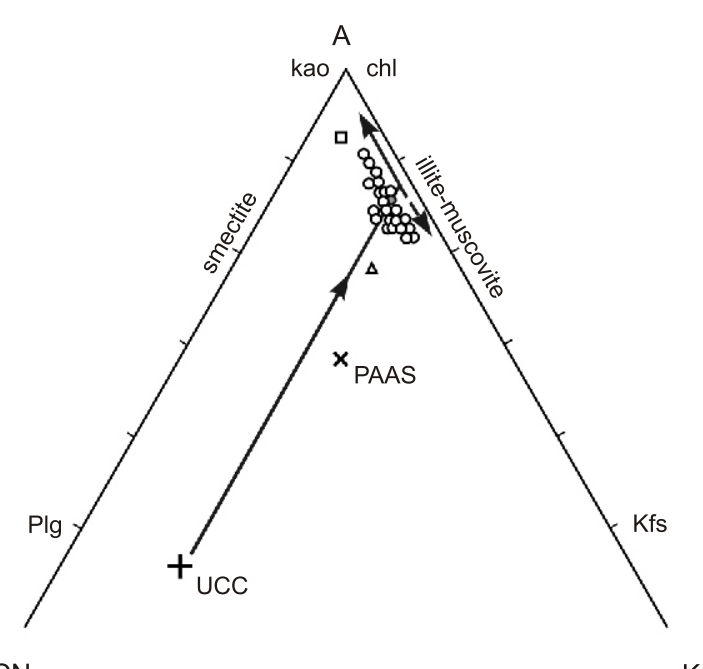

$\mathrm{C}$

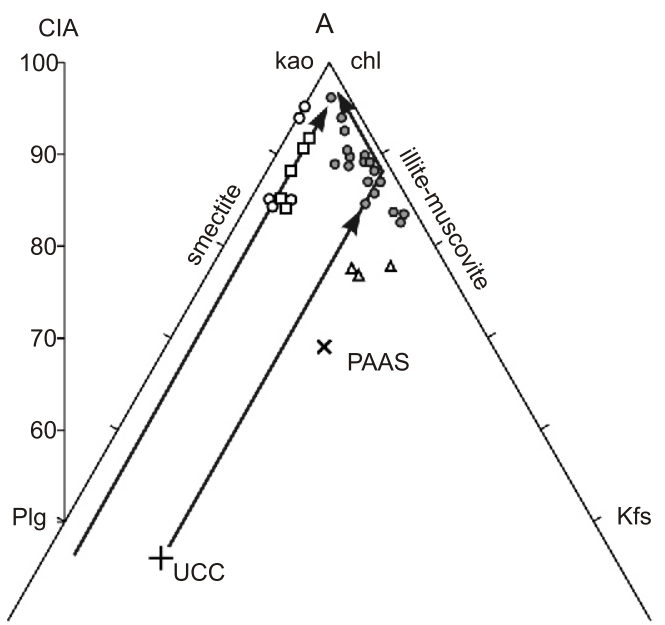

$\mathrm{CN}$

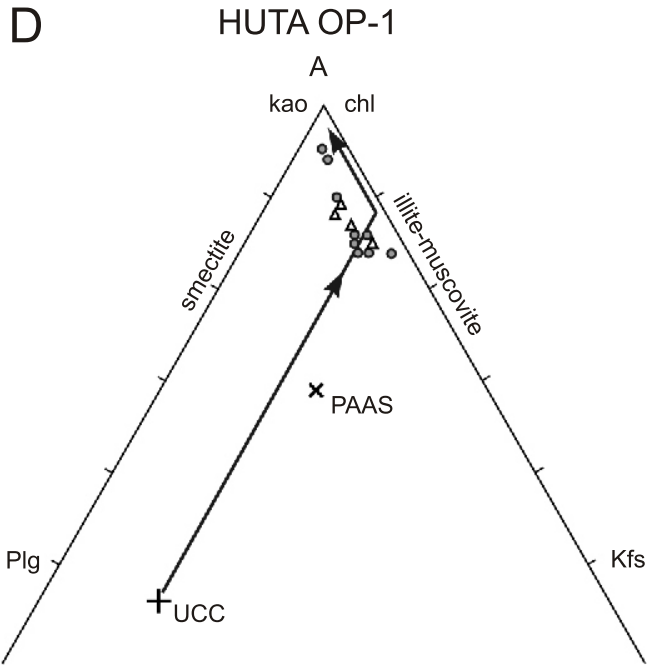

K $\mathrm{CN}$
$\mathrm{K}$

Fig. 9. A-CN-K $\left(\mathrm{Al}_{2} \mathrm{O}_{3}-\mathrm{CaO} *+\mathrm{Na}_{2} \mathrm{O}-\mathrm{K}_{2} \mathrm{O}\right)$ ternary diagrams depicting bulk rock data of the Rhaetian-lowermost Hettangian strata in Polish Basin

Triangles - Zbąszynek Beds (Norian), squares - Wielichowo Beds (Lower-Middle Rhaetian), empty circles - Zagaje Formation (Upper Rhaetian), filled circles - Zagaje Formation (Lower Hettangian), UCC - average composition of Upper Continental Crust and PAAS - average composition of post-Archean Australian Shale (Taylor and McLennan, 1985). Solid arrows mark the predicted average weathering trends of rock samples with UCC composition, and dashed arrow indicates inferred slight diagenetic illitisation (cf. Fedo et al., 1995, 1997). Note that most samples are near the A apex in accordance with the relatively high kaolinite content and intense weathering that removed the large amounts of $\mathrm{Ca}, \mathrm{Na}$ and K. Part of the strata in the Kamień Pomorski and Kaszewy borehole sections seem to be influenced by slight metasomatic processes. Note two different weathering trends in Niekłań that may indicate different primary rocks in the Rhaetian and in the Early Hettangian (Rhaetian samples plot in accordance with weathering trend of mafic rocks close to the $\mathrm{A}-\mathrm{CN}$ join)

Systematic gradual changes in kaolinite content during the Rhaetian are not visible in the borehole cores studied. However, the proportion of kaolinite seems to diminish close to the Triassic-Jurassic boundary in the most complete Kamień section (Fig. 5) and to increase again in the lowermost Hettangian (Figs. 5, 7 and 8). Higher in the Zagaje Formation the kaolinite content significantly decreases (Figs. 7 and 8). Nevertheless, there have been observed a few distinct variations at the
10-20 $\mathrm{m}$ scale in the kaolinite content and in the $\mathrm{K} / \mathrm{l}$ ratio (Brański, 2011a, b). This issue will be a topic of another paper. In contrast to the Rhaetian, the Hettangian profile is continuous and does not contain any significant time gaps (Pieńkowski, 2004) due to the much greater accommodation space of the basin connected mainly with the distinctly higher subsidence rate of the MPT basement in the Early Hettangian (Brański, 2006, 2011a). 
Selected mineralogical and geochemical data that were obtained from the kaolinite "event" layers

\begin{tabular}{|c|c|c|c|c|c|c|c|c|c|c|c|c|c|c|}
\hline L.p. & $\begin{array}{c}\text { Borehole } \\
\text { section }\end{array}$ & $\begin{array}{c}\text { Sample/ } \\
\text { depth }[\mathrm{m}]\end{array}$ & $\begin{array}{l}\text { Lithostrati- } \\
\text { graphy }\end{array}$ & Substage & $\begin{array}{c}\Sigma \text { clay } \\
\min . \\
{[\%]}\end{array}$ & $\begin{array}{c}\text { kaoli- } \\
\text { nite } \\
{[\%]^{*}}\end{array}$ & $\mathrm{~K} / \mathrm{I}$ & $\underset{\mathrm{Ch}}{\mathrm{K} / \mathrm{I}}$ & $\mathrm{K} / \mathrm{Sm}$ & $\mathrm{CIA}$ & CIW & PIA & $\mathrm{Al} / \mathrm{K}$ & $\mathrm{Al} / \mathrm{Na}$ \\
\hline 1 & \multirow{5}{*}{$\begin{array}{c}\text { Kamień } \\
\text { Pomorski }\end{array}$} & $\mathrm{KP} / 676.8$ & \multirow{4}{*}{$\begin{array}{c}\text { Zagaje } \\
\text { Formation }\end{array}$} & L. Hettangian & 51 & 71 & 2.4 & 2.4 & - & 82.6 & 93.2 & 92.2 & 7.2 & 17.6 \\
\hline 2 & & $\mathrm{KP} / 684.4$ & & \multirow{3}{*}{$\begin{array}{l}\text { Upper } \\
\text { Rhaetian }\end{array}$} & 64 & 70 & 2.3 & 2.3 & - & 80.9 & 92.9 & 91.6 & 6.3 & 15.4 \\
\hline 3 & & $\mathrm{KP} / 691.0$ & & & 91 & 68 & 2.1 & 2.1 & - & 89.5 & 91.3 & 91.1 & 45.3 & 12.4 \\
\hline 4 & & $\mathrm{KP} / 692.9$ & & & 83 & 86 & 4.8 & 4.8 & - & 90.0 & 93.1 & 92.9 & 27.0 & 16.2 \\
\hline 5 & & $\mathrm{KP} / 699.3$ & $\begin{array}{c}\text { Wielichowo } \\
\text { Beds }\end{array}$ & L.-M. Rhaetian & 85 & 69 & 2.2 & 2.2 & - & 90.9 & 92.9 & 92.8 & 41.5 & 15.6 \\
\hline 6 & Kaszewy & $\mathrm{K} / 1965.2$ & $\begin{array}{c}\text { Wielichowo } \\
\text { Beds }\end{array}$ & L.-M. Rhaetian & 85 & 86 & 6.1 & 6.1 & - & 92.6 & 95.5 & 95.4 & 30.7 & 30,7 \\
\hline 7 & \multirow{5}{*}{ Niekłań } & $\mathrm{Nk} / 157,7$ & \multirow{3}{*}{$\begin{array}{c}\text { Zagaje } \\
\text { Formation }\end{array}$} & L. Hettangian & 65 & 73 & 3.3 & 2.7 & - & 94.0 & 97.4 & 97.3 & 27.0 & 63.0 \\
\hline 8 & & $\mathrm{Nk} / 162.3$ & & \multirow{2}{*}{$\begin{array}{l}\text { Upper } \\
\text { Rhaetian }\end{array}$} & 64 & $\sim 100$ & - & - & - & 94.9 & 95.4 & 95.4 & 206.0 & 41.2 \\
\hline 9 & & $\mathrm{Nk} / 164.3$ & & & 65 & $\sim 100$ & - & - & - & 93.9 & 94.3 & 94.3 & 215.0 & 35.8 \\
\hline 10 & & Nk/169.3 & \multirow{2}{*}{$\begin{array}{l}\text { Wielichowo } \\
\text { Beds }\end{array}$} & \multirow{2}{*}{$\begin{array}{c}\text { Lower-Middle } \\
\text { Rhaetian }\end{array}$} & 80 & 87 & - & - & 6.7 & 92.5 & 94.1 & 94.0 & 55.8 & 46.6 \\
\hline 11 & & $\mathrm{Nk} / 178.4$ & & & 68 & 90 & 18.0 & 9.0 & - & 91.1 & 93.1 & 93.0 & 40.8 & 32.6 \\
\hline 12 & Huta & $\mathrm{Ht} / 183.5$ & $\begin{array}{c}\text { Zagaje } \\
\text { Formation }\end{array}$ & L. Hettangian & 62 & 55 & 1.9 & 1.2 & - & 94.6 & 97.0 & 96.9 & 38.2 & 95.5 \\
\hline
\end{tabular}

* - percentage of total amount of clay minerals; other explanations are in the text

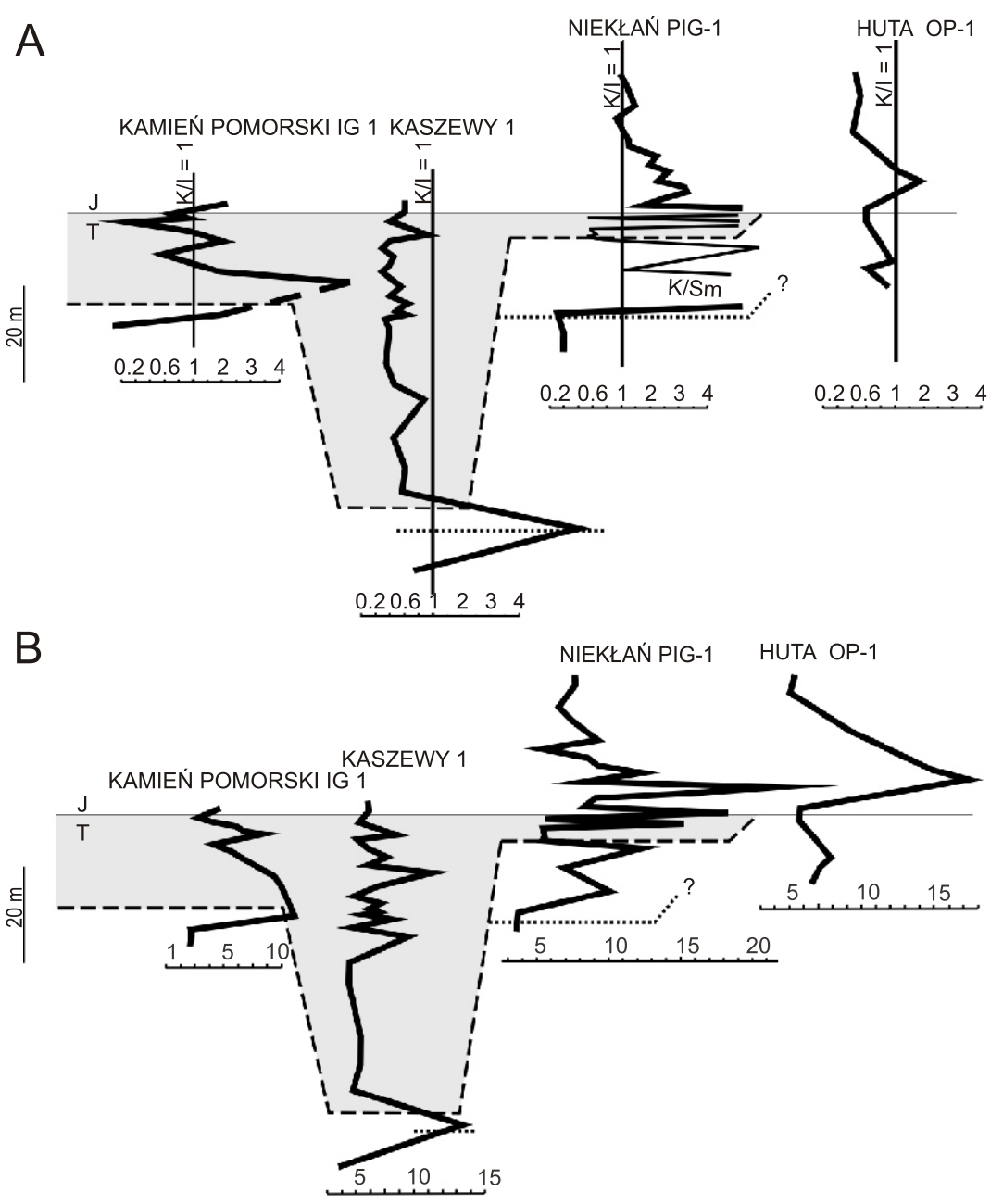

Fig. 10A - kaolinite/illite ratio and $\mathrm{B}-\mathrm{CIA}^{*}$ values - a comparison

Shaded area - Upper Rhaetian; dotted lines - Norian-Rhaetian boundary; note the series of frequent and rapid shifts of both curves in the section studied: the first one in the earlier Rhaetian, later ones in the Late Rhaetian and the last one in the earliest Hettangian 
It should be strongly emphasized the distinct surges of kaolinite content observed in some beds in the Rhaetian and at the beginning of Hettangian (Table 5) mark the kaolinite spikes on clay mineral ratio curves (set together in Fig. 10A). Moreover, the first rise of kaolinite content appeared already earlier in Rhaetian, i.e. in the Wielichowo Beds (Figs. 5-7 and 10A). Next, similar peaks are observed in some beds of the Zagaje Fm. and correspond to rapid increases in kaolinite during the Late Rhaetian (Figs. 5-7 and 10A) and later at the beginning of the Hettangian (Figs. 5, 7, 8 and 10A). The kaolinite peaks usually correlate with the highest values of weathering indices (Figs. 5-8 and 10B) and in most cases CIA values are greater than 90, and CIW and PIA values are even higher (Table 5). Nevertheless some discrepancies were also observed, especially in the Kamień borehole section (Fig. 5 and Table 5).

\section{INTERPRETATION AND DISCUSSION}

\section{DIAGENESIS}

Before any palaeoenvironmental and palaeoclimatic interpretation of clay mineral assemblages, it is necessary to estimate the potential diagenetic impact. Most lithofacies in the Polish Basin correspond to massive claystones and mudstones which are weakly permeable to fluid migration. There is no distinct and systematic evolution of clay-mineral assemblages from top to bottom of the boreholes studied that would be indicative of burial diagenesis. Moreover, selected SEM observations indicate that clay minerals in the samples analysed are mainly detrital (Fig. 4A) and show a weak diagenetic overprint. Signs of alteration of feldspar into kaolinite (Fig. 4B) are sparse and authigenic kaolinite was rarely observed. Fibrous illite was not detected at all. In most of the XRD data, narrow peaks of illite and chlorite were observed that indicate good crystallinity of these minerals. Almost exclusively the 2M1 illite polytype was observed in the sections studied. The inherited 2M1 illite is mostly considered to be of detrital origin (Grathoff and Moore, 1996). Detrital, highly illitic I/S mixed-layer minerals are very sparse and also seem to originate from the erosion of rock substrates. Smectite and kaolinite commonly form during weathering and soil-forming processes (Chamley, 1989; Weaver, 1989). Kaolinite derived from highly weathered soils is usually disordered (Hughes and Brown, 1979). Indeed, the kaolinite observed in the sections studied commonly represents the $1 \mathrm{Md}$ polytype. Importantly, smectite is abundant in the Lower-Middle Rhaetian Wielichowo Beds despite its sensitivity to diagenetic alteration. Thus, the lack (or negligible amounts) of smectite in the Upper Rhaetian-Lower Hettangian Zagaje Formation reflects rather its original absence than the effect of burial diagenesis.

The total burial depth of uppermost Triassic-lowermost Jurassic deposits in the Holy Cross Mts. area and in the Pomeranian segment of MPT was mostly in the range of 1500-2000 m (Resak et al., 2008; Brański, 2009, 2011a; Narkiewicz et al., 2010; Słowakiewicz and Poprawa, 2010), indicating that the Rhaetian-Hettangian strata studied were not significantly modified by thermal diagenesis. In addition, the time during which the lithostatic load in the MPT attained maximum values is estimated at only 20-30 My (Brański, 2011a), which prevented long-lasting diagenetic conditions. The maximum burial temperature of the Rhaetian-Hettangian in the Niekłań and Huta sections, as well as in the Kamien Pomorski section, may be estimated at $60-80^{\circ} \mathrm{C}$. The low thermal alteration of the Rhaetian-Hettangian continental strata in the Polish Basin was confirmed by palynomorph colours (Pieńkowski and Waksmundzka, 2009) and biomarkers (Marynowski and Simoneit, 2009). Moreover, a focus of this study is the kaolinite content that is resistant under moderate diagenetic conditions (Kozłowska, 2004 and references therein). A burial temperature of about $60-80^{\circ} \mathrm{C}$ excludes the kaolinite-to-illite transformation in the borehole sections: Kamień Pomorski, Niekłań and Huta. In the Kuyavyan segment of the MPT, burial history data are sparse. However, burial depth was locally much greater and the burial temperature of Rhaetian-Hettangian in vicinity of Kaszewy borehole seems to exceed $100^{\circ} \mathrm{C}$ (cf. Zielinski et al., 2012). Regardless of that, some others metasomatic changes cannot be excluded. Several authors suggest a widespread Early to Middle Jurassic hydrothermal event that was expressed subparallel to the major structural trend of the MPT, perhaps along pre-existing trending faults (Kozłowska and Poprawa, 2004; Zielinski et al., 2012). Therefore, the thickness necessary for the given level of diagenesis may have been reduced in some places by elevated heat flow along this major tectonic zone.

Summing-up, the clay minerals in the sections studied are largely detrital and show mostly an insignificant diagenetic overprint, due to moderate burial and to the generally closed hydrologic system. Detrital clay minerals in Polish Basin are considered to represent for the most part a primary assemblage derived from the provenance area and then deposited in the alluvial-lacustrine environments that developed during Rhaetian-Hettangian time. Therefore, they may help to reconstruct the palaeoenvironmental and palaeoclimatic conditions then existing. However, some metasomatic changes cannot be locally excluded and a moderate diagenetic overprint would weaken the palaeoenvironmental signal in the Kaszewy section.

GENERAL PALAEOENVIRONMENTAL AND PALAEOCLIMATIC REMARKS

Norian mudrocks were not actually the main goal of investigations here. A distinct domination of illite (with chlorite) in the Zbasszynek Beds and comparatively low values of chemical indices (Fig. 7) are clearly related to hydrolysis inhibition and to physical weathering in a hot, semi-dry climate in the Norian. Some layers in the Huta section are less typical (cf. Wiewióra and Wyrwicki, 1977; Brański, 2007b) and may have been altered by the early diagenesis that increased the kaolinite content. The erosion and redeposition of supplementary kaolinite from earlier weathered profiles (that developed in the source areas) also cannot be excluded.

The dominance of smectite in most of the Lower-Middle Rhaetian Wielichowo Beds may indicate some increase in precipitation and in seasonality compared with the Norian. Smectites are detrital and mostly represented by beidellite (Kozydra and Wyrwicki, 1977) that forms in soils. Warm and seasonally humid climate conditions and tectonic stability during the Early-Middle Rhaetian favoured the development of vertisols in the source areas, which led to the abundance of beidellite in sediments of the Polish Basin. In the upper part of Wielichowo Beds, a basic change in the clay mineral assemblage is observed (Figs. 5-7 and 10A), which reflects a distinct increase in climate humidity during the Rhaetian with a shift from smectite- to kaolinite-dominated mudrocks.

The following Zagaje Formation is crucial to this paper, because the Triassic-Jurassic boundary was determined here (Pieńkowski 2004; Pieńkowski et al., 2012). Generally, in the Zagaje Formation, the kaolinite-illite association prevails and it signifies the predominance of warm climate with high round-year rainfall. In detail, however, the Upper Rhaetian clay 
mineralogy is more complicated. The clay fraction of the lower part of the Zagaje Fm. (Late Rhaetian in age) shows significant differences from one section to another. The time span of the smectite enrichment is not uniform. The smectite-dominated interval in the Niekłań section continues in the lowermost part of the Zagaje Formation (Fig. 7). This suggests the existence of additional local reasons for smectite deposition that overlap with the climate record. The weathering of mafic rocks may have induced the secondary formation of smectite in the Niekłań vicinity and other localities what was also suggested by the $\mathrm{Al} / \mathrm{Ti}$ ratio and the $\mathrm{A}-\mathrm{CN}-\mathrm{K}$ diagram (see below). In turn, a significant content of berthierine and serpentine is observed in the upper Rhaetian part of the Zagaje Fm. in the Kamien section (Figs. $3 \mathrm{C}$ and 5). The origin of berthierine is still controversial. Most probably it forms very early in diagenesis (Hornibrook and Longstaffe, 1996), by reaction of kaolinite and Fe-oxides (Sheldon and Retallack, 2002), as part of a lateritic weathering profile developed on a broad, low-relief peneplain particularly in a swampy environment (Toth and Fritz, 1997). Primary crystallization of berthierine demands a supply rich in iron, readily soluble volcanic rock material and a high organic matter content (Hornibrook and Longstaffe, 1996); however, low levels of sulfide and bicarbonate are also required (Toth and Fritz, 1997; Sheldon and Retallack, 2002). Otherwise, the formation of pyrite and siderite is favoured, respectively. According to Hornibrook and Longstaffe (1996), the reducing environment should be marginally more oxic than the environment in which siderite precipitates. According to Sheldon and Retallack (2002), the occurrence of berthierine in palaeosols may indicate soil oxygen consumption by the influx of atmospheric methane to form carbon dioxide, in turn giving rise to greenhouse conditions. In other words, soil oxygen might be consumed by the oxidation of methane to form carbon dioxide, leading to dysoxia and hypercapnia in Rhaetian soils. In the Polish Basin, the berthierine- and serpentine-containing samples are here related to mudrocks deposited in alluvial-lacustrine environments (Fig. 5), but typical swamp-related deposits are observed only sporadically in the Rhaetian (Pieńkowski et al., 2012). Interestingly, only the mudrocks from Kamien borehole section contain berthierine in significant amounts. Most probably, erosion of berthierine-containing palaeosols and lateritic covers in the source area (the Baltic Shield) may have contributed detrital berthierine to alluvial-lacustrine sediments in Pomerania. The delivery of serpentine is also probably linked to the co-occurrence of weathered ultramafic rocks in the northern hinterland of the Polish Basin (Fig. 2). The Al/Ti ratio of some samples is here even less than 10 (Table 3). Other sections studied were supplied with deposits from different source areas (Fig. 2). Regardless of that, berthierine is considered to be easily transformed into chlorite during burial diagenesis (Hillier, 1994; Aagaard et al., 2000). Indeed, chlorite does not occur in Kamień although it is rather commonly observed in other places in which berthierine-to-chlorite transformation is not excluded. One way or another, the presence of berthierine (that like kaolinite is connected with lateritic cover) suggests humid tropical conditions north of the Polish Basin, thus at fairly high latitudes. This supports the idea of a global greenhouse event (or events) in the Late Rhaetian.

After a probably cooler and less humid interval around the TJB (see Korte et al., 2009) the degree of chemical weathering increased again in the earliest Hettangian (Figs. 7, 8 and 10A) due to a return of greenhouse conditions that is recorded in the Niekłań and Huta borehole sections by a kaolinite abundance. Upsection, the amount of the kaolinite diminishes (by contrast with the illite and chlorite content), reflecting a decrease in humidity or increasing delivery of immature material from source areas, because of tectonic rejuvenation and a subsidence pulse in the MPT at the very beginning of Jurassic (Brański, 2006, 2011a). A generally stable kaolinite-illite-chlorite assemblage in the Hettangian may have resulted from increased run-off following tectonic rejuvenation. Nevertheless, the relative abundance of kaolinite suggests this event could also have been accompanied by significant hydrolysis that masked tectonic signal to some extent.

The geochemical data are generally consistent with the clay mineralogy results. Progressive chemical weathering leaches and removes the soluble elements $(\mathrm{Ca}, \mathrm{Na}, \mathrm{Mg}$ and finally $\mathrm{K}$ ) relative to $\mathrm{Al}$ and, in some cases, $\mathrm{Fe}$ and $\mathrm{Ti}$ (e.g., Nesbitt and Young, 1982; Fedo et al., 1995, 1997; Tosca et al., 2010). This reflects the decrease in abundance of both non-clay silicate minerals (plagioclases, K-feldspars) and compositionally immature clay minerals such as smectite (cf. Weaver, 1989). The values of weathering indices (Table 3 and 4 ) overlap significantly in most cases with those characteristic of modern residual clays or muds from rivers draining strongly weathered tropical areas such as Central Uganda, where CIA values fluctuating from 87 to 96 were recorded, and where the CIW values range between 96 to 99 (Nyakairu and Koeberl, 2001). Those sediments were derived mainly from highly acidic rocks (Nyakairu and Koeberl, 2001), thus generally more felsic than in the case of the sections described in the present paper. In particular, the weathering indices values in Kamien are significantly lower than in other sections due to the different parent-rock petrology in the source areas.

The extent of weathering is clearly visible in the triangular A-CN-K diagrams (Fig. 9) that allow the differentiation of compositional changes (cf. Fedo et al., 1995). In the figure, the solid arrows mark the predicted average weathering trends of rock samples of UCC composition. In A-CN-K compositional space, the chemical weathering trends are roughly parallel to the A-CN boundary, and subsequent progressive weathering is directed towards the A apex (Fedo et al., 1997). Most of the Rhaetian-lowermost Hettangian samples are near the A apex (Fig. 9) in accordance with relatively high kaolinite content and strong weathering that removed large amounts of $\mathrm{Ca}, \mathrm{Na}$ and $\mathrm{K}$. In the Niekłań and Huta borehole sections weathering took place almost without any diagenetic impact (Fig. 9C, D). The relatively wide variation in the CIA values from the Niekłań borehole and the two different weathering trends may indicate different source rocks in the Rhaetian and in the Early Hettangian. Rhaetian samples plot in accordance with the weathering trend of mafic rocks close to the A-CN join (e.g., Nesbitt and Young, 1982; Fedo et al., 1995, 1997). This trend concurs with a lower $\mathrm{Al} / \mathrm{Ti}$ ratio and with surprisingly large (also in the Upper Rhaetian) content of smectite (Table 3), which is frequently a chemical weathering product of ferromagnesian aluminosilicates (Chamley, 1989; Liu et al., 2012). Parts of the Kamień and Kaszewy sections seem also to be influenced by postdepositional processes to some extent (Fig. 9A, B). This alteration has probably reduced somewhat the values of $\mathrm{CIA}$, and in places of other chemical indices. Moreover, Rhaetian major elements data from the Kamień borehole (Fig. 9A) suggest the mixing of clays derived from different source rocks. More moderate CIA, CIW and PIA values (Tables $2-5$ ) may be explained by progressive delivery of unweathered material from the hinterland. The influence of postdepositional moderate Na-metasomatism cannot also be excluded because many bulk rock samples from this core are unexpectedly enriched in $\mathrm{Na}$ (the average Na content in samples from Kamien is two to three times higher than in the other sections studied). In the Kaszewy borehole section the sample data lies in a fairly tight cluster along the A-K join, mostly quite near to the A apex (Fig. 9B). 
Nevertheless, some data are somewhat shifted from the predicted weathering trend towards the muscovite-illite field. This small shift may suggest some enrichment in potassium most probably because of slight diagenetic illitization during burial (dashed arrow). This is consistent with the more illitic nature of samples from the Kaszewy section (the amounts of illite almost always exceed those of kaolinite; Fig. 6). The burial temperature of the Rhaetian-Hettangian in this part of MPT probably exceeded significantly $100^{\circ} \mathrm{C}$ (cf. Zielinski et al., 2012). Alternatively, the source rocks were here more felsic than others.

\section{CATASTROPHIC CLIMATIC EVENTS}

Firstly, we may consider the problem of the time demand of palaeosol development and delay between the time of clay minerals formation and their deposition in the sedimentary basin. According to Thiry (2000), this may be quite significant and exceed $1 \mathrm{Ma}$. Such a long duration may concern in particular thick ancient weathering covers. By contrast to Thiry (2000), many recent studies suggest that clay minerals deposited in sedimentary basins are reliable proxies for high-frequency climate fluctuations (e.g., Dera et al., 2009; Srivastava et al., 2010; Alizai et al., 2012; Moiroud et al., 2012; Das et al., 2013). Dera et al. (2009) suggested that formation of kaolinite in tropical soils and its deposition in marine sediments could be almost contemporaneous, i.e. the elapsed time might have been less than $100 \mathrm{ka}$, during the Early Jurassic in the Peritethyan domain. Other papers have demonstrated the potential of clay minerals as a proxy for orbital calibration in Mesozoic times including precession cycles (e.g., Moiroud et al., 2012) and even Holocene monsoonal oscillations of 1000 years (Das et al., 2013). A soil-forming interval of 8-13.5 ka was calculated for the thick mature palaeosols of the Ganga Plains (Srivastava et al., 2010). Importantly, new data from the Holocene Indus floodplain show that changes in clay mineralogy postdate the climate shifts by only $3-5 \mathrm{ka}$, embracing the time needed for new clay minerals to form and be transported to the river mouth (Alizai et al., 2012). Nevertheless, the same authors conclude that clay minerals are not good weathering proxies at time scales of $\sim 1000 \mathrm{yr}$ or less. The present paper also suggests a short-duration response of detrital clay minerals to climate fluctuations.

Importantly, some beds with very high $\mathrm{K} / \mathrm{I}$ ratio and strongly elevated values of chemical indices were observed in the studied sections (Table 5 and Fig. 10). The sharp increase in kaolinite content records an abrupt change in weathering regime. Those layers particularly rich in kaolinite with usually very high CIA values were developed as a result of extreme chemical weathering of source terrains in the aftermath of rapid greenhouse warming and abundant rainfall. The extreme weathering of bedrock, and soil erosion, was probably exacerbated by acid rain and subsequent deforestation due to the CAMP-related emission of sulfur and carbon dioxide (Schootbrugge et al., 2009). Distinct episodic warming and contemporaneous humid events are indicated by the high abundance of kaolinite coupled with disappearance of smectite, which suggests hot and wet tropical conditions with low seasonality contrasts. Strong and rapid leaching removed almost all mobile alkali and alkaline earth elements. In triangular A-CN-K diagrams (Fig. 9), the samples from these kaolinite layers, with $\mathrm{CIA}$ values significantly greater than 90 , lie mostly the closest to the A apex due to near-complete alteration of their feldspars. PIA and CIW values of 96-98 indicate that almost all plagioclase was converted to clay minerals (especially to kaolinite). Several characteristic kaolinite peaks mostly con- firmed by high values of chemical indices may be defined in the sections studied. The first, Early to Middle Rhaetian greenhouse event is recorded by the Wielichowo Beds; a few occur in the Late Rhaetian, and finally last distinct kaolinite episode was detected in the lowermost Hettangian (Figs. 5-8, 10A and Table 5). However, the first and last of these are registered particularly clearly. The record of Late Rhaetian events is most visible in the Kamien borehole section (Fig. 5) that is stratigraphically most complete (Pieńkowski et al., 2012). In other profiles, some events are less clear and more controversial because of the erosive character of this sequence and the diversity of the parent rocks (Niekłań - Fig. 7) or suspected slight diagenetic modification (Kaszewy - Fig. 6). As noted above, in the Huta borehole section the Rhaetian is most likely completely eroded (Fig. 8).

High amounts of kaolinite were also reported from the Rhaetian-Hettangian sections in southern Sweden (Ahlberg et al., 2002, 2003), from the Tatra Mts. in Slovakia (Michalík et al., 2010), and from the topmost Triassic Triletes beds in the German Basin (Schootbrugge et al., 2009). Recently, distinct kaolinite enrichment has also been documented from the topmost Triassic Kössen Formation (Eiberg Basin) in Austria (Pálfy and Zajzon, 2012; Zajzon et al., 2012).

Similar events were observed by Pieńkowski et al. (2012) on carbon isotope curve in the Kamień section (Fig. 5) as well as in many sections worldwide. The inception of the CAMP initiated multiple phases of disturbance of global biogeochemical cycles. The "initial" and "main" negative CIEs are suggested by most authors to be temporally related to the major volcanic phase of CAMP development (Hesselbo et al., 2002, 2007; Korte et al., 2009; Deenen et al., 2010; Whiteside et al., 2010). Initial carbon release at the onset of CAMP emplacement may have activated a strong positive feedback resulting in further release of methane from hydrates (Hesselbo et al., 2002, 2007; Beerling and Berner 2002; Ruhl et al., 2011). The sudden increase in atmospheric greenhouse gases concentrations likely caused a global super-greenhouse (McElwain et al. 1999; Whiteside et al. 2010), at the end of the Triassic. The upper "sub-peak" of the "initial" CIE in the Kamień section is also associated with perturbations of the osmium isotope system (attributed to volcanic fallout) and darkened miospores suggesting acid rains (Pieńkowski et al., 2012). Between the "initial" excursion and the TJB, climatic fluctuations are inferred, associated with the changing $\mathrm{K} / \mathrm{I}$ ratio (Fig. 5), Os isotope system perturbation, polycyclic aromatic hydrocarbon $(\mathrm{PAH})$ releases and darkened miospores (Pieńkowski et al., 2014). Distinct kaolinite enrichment and abrupt shift of weathering indices in the lowermost Hettangian samples (Figs. 5, 7, 8 and 10) may be correlated with the onset of long-term warming followed transitional cooling at the TJB (cf. Korte et al., 2009).

However, the end-Rhaetian "initial" negative CIE was preceded by prior Rhaetian negative excursions that indicate possible multiple events in the Rhaetian carbon cycle. In many sections worldwide, as well as in the Polish Basin (Wielichowo Beds - Pieńkowski et al., 2012), a distinct short-term negative C-isotope excursion records a greenhouse methane release triggered by warming event earlier in Rhaetian. Existence of a distinct Rhaetian "precursor" negative CIE (Ruhl and Kürschner, 2011) or "Westbury" negative CIE (Suan et al., 2011) or "Neg-1" CIE (Lindström et al., 2012) indicate the beginning of environmental perturbations and suggests that global carbon cycle disturbance predates by some 100-200 kyr the onset of CAMP flood basalt deposition (Blackburn et al., 2013). Most probably, extensive Late Triassic dike and sill intrusions initially released thermogenic methane and other volatiles from subsurface organic-rich deposits (Ruhl and Kürschner, 2011). 
Alternatively, it is possible that an earlier flood basalt episode is still to be discovered (Pieńkowski et al., 2014). This earlier Rhaetian episode is very well reflected in clay mineral and chemical data from the Kamień, Kaszewy and Niekłań borehole sections. In Kamień Pomorski and Niekłań, the smectite-rich sedimentation of Wielichowo Beds was interrupted by sudden kaolinite input (Figs. 5 and 7). In the Kaszewy borehole, kaolinite content also increases rapidly at a similar time (Fig. 6).

In the Kamień section (Fig. 5), a positive kaolinite peak either coincides with negative carbon isotope excursion (just as in the case of the "precursor" CIE) or it is observed approximately one meter below the $\delta^{13} \mathrm{C}$ anomaly (in the case of the major "initial" CIE). This latter case suggests that onset of warming (possibly subsequent to the volcanic $\mathrm{CO}_{2}$ degassing) may slightly precede catastrophic perturbations of global carbon cycle caused most probably by methane hydrate dissociation (cf. Slujis et al., 2007; Hermoso et al., 2012; Brański, 2012). The former seems to indicate another mechanism of carbon cycle disturbance, possibly thermogenic methane release during the intrusive phase of igneous province development and immediate warming. However, much higher sampling resolution is needed to constrain this. Moreover, carbon isotopes have not yet been analysed in other borehole sections from Polish Basin.

Regardless of the warming episodes, periods of weaker chemical weathering have also been recorded in some layers characterized by lower kaolinite content and smaller values of weathering indices. Because the Rhaetian was a time of tectonic quiescence, the relative kaolinite depletions and distinct enrichments in illite and chlorite were related to weakened hydrolysis and an increase in physical weathering intensity caused by drier and probably cooler episodes. Moreover, the alternating deposition of smectite-rich clay and of kaolinite-rich clay that appears locally in the Late Rhaetian (Fig. 7) may reflect alternating phases of strong continuous and less strong discontinuous hydrolysis, determined by the alternation of round-year humid climatic conditions and seasonal more arid climatic conditions. However, in this case the parent-rock diversity should be also taken in consideration. The weathering of mafic rocks may have induced the secondary formation of smectite at some localities, regardless of climate fluctuations.

Summing-up, rapid and episodic fluctuations in the clay mineralogical composition and in the values of weathering indices (Fig. 10) point to a sequence of frequent and marked climatic reversals. Some of these (Fig. 5) seem correspond to the major Late Rhaetian "initial" $\delta{ }^{13} \mathrm{C}$ excursion (Pieńkowski et al., 2012). A profound climate destabilisation that manifested in a series of rapid, catastrophic climatic reversals, coupled with emission of diverse toxic compounds related to CAMP development, were most probably the fundamental reasons of the end-Triassic ecological disaster and mass-extinction (cf. Schootbrugge et al., 2009; Pieńkowski et al., 2012, 2014).

\section{CONCLUSIONS}

Data presented in this paper are based on a continental record that has been calibrated in terms of sequence stratigraphy, palynostratigraphy and chemostratigraphy (Pieńkowski, 2004; Pieńkowski et al., 2012). In general, the original Rhaetian-Lower Hettangian clay mineral assemblage in the Polish Basin was mildly modified by diagenetic processes and by the erosion and redeposition of ancient sedimentary rocks. Therefore, the clay mineral record from the epicontinental Polish Basin allows one to follow the evolution of the strikingly variable weathering conditions through the Rhaetian to Early Hettangian, although gaps in the Rhaetian profile are present. The detrital clay mineral composition of the fine-grained deposits ( $<2 \mu \mathrm{m}$ fraction) and especially vertical variations in kaolinite content were mostly controlled by a weathering regime linked to climatic conditions (especially rainfall fluctuations). However, other factors (differences in source area lithologies, sediment supply variations, and a strike-slip tectonic event at the beginning of the Hettangian) also controlled the mineralogy and geochemistry of Rhaetian-Hettangian deposits in the Polish Basin and locally may overprint a palaeoclimatic signals to some extent. Nevertheless, the following conclusions may be made:

1. Generally, after semi-dry climate conditions in Norian times (a distinct domination of illite, relatively low values of weathering indices), smectite domination in most parts of the Lower-Middle Rhaetian Wielichowo Beds points to some increase in precipitation and its distinct seasonality. In the upper part of the Lower Rhaetian Wielichowo Beds and in the Upper Rhaetian-lowermost Hettangian Zagaje Formation, a kaolinite-illite association prevails that signifies the year-round rainfall. Additionally, the presence of siderite and locally of berthierine (and the disappearance of carbonates) also indicates increasing humidity. Higher in the Lower Hettangian, the amount of kaolinite diminishes, reflecting some decrease in humidity and/or increasing delivery of immature material, because of tectonic rejuvenation at the beginning of the Jurassic.

2. Regardless of general changes, some beds particularly rich in kaolinite with very high values of weathering indices point to episodes of extreme chemical weathering in the aftermath of catastrophic climate shifts (rapid warming and abundant rainfall). Moreover, these kaolinite enrichments in the Rhaetian and at the beginning of the Hettangian are generally consistent with prominent negative CIEs from sections in the Polish Basin and in different parts of the world that record super-greenhouse events at this level. Importantly, the Late Rhaetian-earliest Hettangian "greenhouse" warming with growing humidity was punctuated by drier and most probably cooler episodes, as shown by relative kaolinite depletions, distinct enrichments in illite and chlorite, and declines in values of weathering indices. This destabilization, expressed by frequent and catastrophic climatic reversals, coupled with emission of toxic compounds and acid rains related to CAMP development, seem to have been an important reason for the end-Triassic ecological disaster and mass extinction.

Acknowledgements. This paper is a part of the project, financed by the Polish National Science Centre, granted on the basis of decision no. DEC-2012/06/M/ST10/00478. Some data from PGI project no. 61.3608.0801.00.0 were also included. The studies were carried out at Polish Geological Institute - National Research Institute in Warsaw. XRD, XRF, SEM and TOC analyses were performed by W. Narkiewicz, I. Iwasińska-Budzyk, L. Giro and M. Jaskólska, respectively. I thank B. Raucsik and O. Lintnerová for their constructive and insightful reviews that improved the original manuscript. W. Markowski is acknowledged for his help with the drafting of figures. 


\section{REFERENCES}

Aagaard, P., Jahren, J.S., Harstad, A.O., Nilsen, O., Ramm, M., 2000. Formation of grain-coating chlorite in sandstones. Laboratory synthesize vs. natural occurrences. Clay Minerals, 35 261-269.

Ahlberg, A., Arndorff, L., Guy-Ohlsson, D., 2002. Onshore climate change during the Late Triassic marine inundation of the Central European Basin. Terra Nova, 14: 241-248.

Ahlberg, A., Olsson, I., Šimkevičius, P., 2003. Triassic-Jurassic weathering and clay mineral dispersal in basement areas and sedimentary basins of southern Sweden. Sedimentary Geology, 161: $15-29$

Alizai, A., Hillier, S., Clift, P.D., Giosan, L., Hurst, A., Laningham, S., van, Macklin, M., 2012. Clay mineral variations in Holocene terrestrial sediments from the Indus Basin. Quaternary Research, 77: 368-381.

Beerling, D.J., Berner, R.A., 2002. Biogeochemical constraints on the Triassic-Jurassic boundary carbon cycle event. Global Biogeochemical Cycles, 16, art. no.1036

Blackburn, T.J., Olsen, P.E., Bowring, S.A., McLean, N.M., Kent, D. V., Puffer, J., McHone, G., Rasbury, T., 2013. Zircon U-Pb geochronology links the end-Triassic extinction with the Central Atlantic Magmatic Province. Science, 340: 941-945.

Bonis, N.R., Konijnenburg-Cittert, J.H.A., van, Kürschner, W.M., 2010. Changing $\mathrm{CO}_{2}$ conditions during the end-Triassic inferred from stomatal frequency analysis on Lepidopteris ottonis (Goeppert) Schimper and Ginkgoites taeniatus (Braun) Harris. Palaeogeography, Palaeoclimatology, Palaeoecology, 295: 146-161.

Brański, P., 2006. Lower Hettangian in the Holy Cross Mountains region - an example of tectonically-controlled sedimentation in the epicontinental basin of Poland. Volumina Jurassica, 4 $80-81$

Brański, P., 2007a. Zespoły minerałów ilastych jury dolnej z południowej części epikontynentalnego basenu polskiego wpływ paleoklimatu a inne czynniki. Tomy Jurajskie, 4: 5-18.

Brański, P., 2007b. An estimate of possible use of selected pre-Cenozoic clays from Poland for environmental protection (in Polish with English summary). Przegląd Geologiczny, 55: 467-474.

Brański, P., 2009. Influence of palaeoclimate conditions and greenhouse effect on the Hettangian clay mineral assemblages (Holy Cross Mts. area, Polish Basin). Geological Quarterly, 53 (3): 363-368.

Brański, P., 2010. Kaolinite peaks in early Toarcian profiles from the Polish Basin - an inferred record of global warming. Geological Quarterly, 54 (1): 15-24.

Brański, P., 2011a. Formacja zagajska i przysuska formacja rudonośna jury dolnej $w$ regionie świętokrzyskim: paleotektoniczno-paleogeograficzne uwarunkowania genezy surowców ceramicznych (in Polish). Ph.D thesis. NAG, Warszawa.

Brański, P., 2011b. Clay mineral composition in the Triassic and Jurassic deposits from the Polish Basin - a record of palaeoclimatic and palaeoenvironmental changes (in Polish with English summary). Biuletyn Państwowego Instytutu Geologicznego, 444: 153-32.

Brański, P., 2012. The mineralogical record of the Early Toarcian stepwise climate changes and other environmental variation (Ciechocinek Formation, Polish Basin). Volumina Jurassica, 10 : $1-24$.

Callegaro, S., Rigo, M., Chiaradia, M., Marzoli, A., 2012. Latest Triassic marine $\mathrm{Sr}$ isotopic variations, possible causes and implications. Terra Nova, 24: 130-135.

Chamley, H., 1989. Clay Sedimentology. Springer, Berlin.

Cirilli, S., Marzoli, A., Tanner, L., Bertrand, H., Buratti, N., Jourdan, F., Bellieni, G., Kontak, D., Renne, P.R., 2009. Latest Triassic onset of the Central Atlantic Magmatic Province (CAMP) volcanism in the Fundy Basin (Nova Scotia): new strati- graphic constraints. Earth and Planetary Science Letters, 286: 514-525.

Cleveland, D.M., Nordt, L.C., Dworkin, S.I., Atchley, S.C., 2008 Pedogenic carbonate isotopes as evidence for extreme climatic events preceding the Triassic-Jurassic boundary: implications for the biotic crisis? GSA Bulletin, 120: 1408-1415.

Cohen, A.S., Coe, A.L., 2002. New geochemical evidence for the onset of volcanism in the Central Atlantic Magmatic Province and environmental change at the Triassic-Jurassic boundary. Geology, 30: 267-270.

Cohen, A.S., Coe, A.L., 2007. The impact of the Central Atlantic Magmatic Province on climate and on the $\mathrm{Sr}$ - and Os-isotope evolution of sea water. Palaeogeography, Palaeoclimatology, Palaeoecology, 244: 374-390.

Courtillot, V.E., Renne, P.R., 2003. On the ages of flood basalt events. Comptes Rendus Geoscience, 335: 113-140.

Cox, R., Lower, D.R., Cullers, R.L., 1995. The influence of sediment recycling and basement composition on evolution of mudrock chemistry in the southwestern United States. Geochimica et Cosmochimica Acta, 59: 2919-2940.

Dadlez, R., 1997. Epicontinental basins in Poland: Devonian to Cretaceous relationships between the crystalline basement and sedimentary infill. Geological Quarterly, 41 (4): 419-432.

Dadlez, R., Narkiewicz, M., Stephenson, R.A., Visser, M.T.M., Ven Wees, J.-D., 1995. Tectonic evolution of the Mid-Polish Trough: modelling implications and significance for central European geology. Tectonophysics, 252: 179-195.

Dadlez, R., Narkiewicz, M., Pokorski, J., Wagner, R., 1998. Subsidence history and tectonic controls on the Late Permian and Mesozoic development of the Mid-Polish Trough (in Polish with English summary). Prace Państwowego Instytutu Geologicznego, 165: 47-56

Das, S.S., Rai, A.K., Akaram, V., Verma, D., Pandey, A.C., Dutta, K., Prasad, R.G.V., 2013. Paleoenvironmental significance of clay mineral assemblages in the southeastern Arabian Sea during last $30 \mathrm{kyr}$. Journal of Earth System Science, 122: 173-185.

Deconinck, J-F., Hesselbo, S.P., Debuisser, N., Averbuch, O., Baudin, F., Bessa, J., 2003. Environmental controls on clay mineralogy of an Early Jurassic mudrock (Blue Lias Formation, southern England). International Journal of Earth Science, 92: 255-266.

Deenen, M.H.L., Ruhl, M., Bonis, N.R., Krijgsman, W., Kürschner, W.M., Reitsma, M., Bergen, M.J. van, 2010. A new chronology for the end-Triassic mass extinction. Earth and Planetary Science Letters, 291: 113-125.

Dera, G., Pellenard, P., Neige, P., Deconinck, J.-F., Puceat, E., Dommergues, J.-L., 2009. Distribution of clay minerals in Early Jurassic Peritethyan seas: Palaeoclimatic significance inferred from multiproxy comparisons. Palaeogeography, Palaeoclimatology, Palaeoecology, 271: 39-51.

Fedo, C.M., Nesbitt, H.W., Young, G.M., 1995. Unraveling the effects of potassium metasomatism in sedimentary rocks and paleosols, with implications for paleoweathering conditions and provenance. Geology, 23: 921-924.

Fedo, C.M., Young, G.M., Nesbitt, H.W., Hanchar, J.M., 1997. Potassic and sodic metasomatism in the Southern Province of the Canadian Shield: evidence from the Paleoproterozoic Serpent Formation, Huronian Supergroup, Canada. Precambrian Research, 84: 17-36.

Galli, M.T., Jadoul, F., Bernasconi, S.M., Weissert, H., 2005. Anomalies in global carbon cycling and extinction at the Triassic/Jurassic boundary: evidence from a marine C-isotope record. Palaeogeography, Palaeoclimatology, Palaeoecology, 216: 203-214.

Ganino, C., Arndt, N.T., 2009. Climate changes caused by degassing of sediments during the emplacement of large igneous provinces. Geology, 37: 323-326. 
Goldberg, K., Humayun, M., 2010. The applicability of the Chemical Index of Alteration as a paleoclimatic indicator: an example from the Permian of the Paraná Basin, Brazil. Palaeogeography, Palaeoclimatology, Palaeoecology, 293: 175-183.

Grathoff, G.H., Moore, D.M., 1996. Illite polytype quantification using Wildfire calculated X-ray diffraction patterns. Clays and Clay Minerals, 44: 835-842.

Guex, J., Bartolini, A., Atudorei, V., Taylor, D., 2004. High-resolution ammonite and carbon isotope stratigraphy across the Triassic-Jurassic boundary at New York Canyon (Nevada). Earth and Planetary Science Letters, 225: 29-41.

Haas, J., Budai, T., Raucsik, B., 2012. Climatic controls on sedimentary environments in the Triassic of the Transdanubian Range (Western Hungary). Palaeogeography, Palaeoclimatology, Palaeoecology, 353-355: 31-44.

Hakenberg, M., Świdrowska, J., 1997. Propagation of the south-eastern segment of the Polish Trough connected with bounding fault zones (from the Permian to the Late Jurassic). Comptes Rendus de l'Académie des Sciences, Series IIA Earth and Planetary Science, 324: 793-803.

Hallam, A., Wignall, P.B., 1999. Mass Extinctions and their Aftermath. Oxford University Press, Oxford.

Hames, W.E., Renne, P.R., Ruppel, C., 2000. New evidence for geologically instantaneous emplacement of earliest Jurassic Central Atlantic magmatic province basalts on the North American margin. Geology, 28: 859-862.

Harnois, L., 1988. CIW Index: a new chemical index of weathering. Sedimentary Geology, 55: 319-322.

Hautmann, M., 2004. Effect of end-Triassic $\mathrm{CO}_{2}$ maximum on carbonate sedimentation and marine mass extinction. Facies, $\mathbf{5 0}$ 257-261.

Hautmann, M., Benton, M.J., Tomasovych, A., 2008. Catastrophic ocean acidification at the Triassic-Jurassic boundary. Neues Jahrbuch für Geologie und Paläontologie Abhandlungen, 249: 119-127.

Hayashi, K., Fujisawa, H., Holland, H.D., Ohmoto, H., 1997. Geochemistry of $\sim 1.9 \mathrm{Ga}$ sedimentary rocks from northeastern Labrador, Canada. Geochimica et Cosmochimica Acta, 61: 4115-4137.

Hermoso, M., Minoletti, F., Rickaby, R.E.M., Hesselbo, S.P., Baudin, F., Jenkyns, H.C., 2012. Dynamics of a stepped carbon-isotope excursion: ultra high-resolution study of Early Toarcian environmental change. Earth and Planetary Science Letters, 319-320: 45-54

Hesselbo, S.P., Gröcke, D.R., Jenkyns, H.C., Bjerrum, C.J., Farrimond, P., Bell, H.S.M, Green, O.R., 2000. Massive dissociation of gas hydrate during a Jurassic oceanic anoxic event. Nature, 406: 392-395.

Hesselbo, S.P., Robinson, S.A., Surlyk, F., Piasecki, S., 2002. Terrestrial and marine extinction at the Triassic-Jurassic boundary synchronized with major carbon-cycle perturbation: a link to initiation of massive volcanism? Geology, 30: 251-254.

Hesselbo, S.P., McRoberts, C.A., Pálfy, J., 2007. Triassic-Jurassic boundary events: problems, progress, possibilities. Palaeogeography, Palaeoclimatology, Palaeoecology, 244:1-10.

Hesselbo, S.P., Deconinck, J-F., Huggett, J.M., Morgans-Bell, H.S., 2009. Late Jurassic palaeoclimatic change from clay mineralogy and gamma-ray spectrometry of the Kimmeridge Clay, Dorset, UK. Journal of Geological Society, 166: 1-11.

Hillebrandt, A., von, Krystyn, L., Kürschner, W.M., Bown, P.R., McRoberts, C., Ruhl, M., Simms, M., Tomasovych, A., Urlichs, M., 2007. A candidate GSSP for the base of the Jurassic in the Northern Calcareous Alps (Kuhjoch section, Karwendel Mountains, Tyrol, Austria). International Subcommission on Jurassic Stratigraphy Newsletter, 34: 2-20.

Hillier, S., 1994. Pore-lining chlorites in siliciclastic reservoir sandstones: electron microprobe, SEM and XRD data, and implications for their origin. Clay Minerals, 29: 665-679.

Hornibrook, E.R.C., Longstaffe, F.J., 1996. Berthierine from the lower Cretaceous Clearwater formation, Alberta, Canada. Clays and Clay Minerals, 44: 1-21.
Hughes, J.C., Brown, G., 1979. A crystallinity index for soil kaolins and its relation to parent rock, climate and soil maturity. Journal of Soil Science, 30: 557-563.

Jourdan, F., Marzoli, A., Bertrand, H., Cirilli, S., Tanner, L., Kontak, D.J., McHone, G., Renne, P.R., Bellieni, G., 2009 ${ }^{40} \mathrm{Ar} /{ }^{39} \mathrm{Ar}$ ages of CAMP in North America: implications for the Triassic-Jurassic boundary and the ${ }^{40} \mathrm{~K}$ decay constant bias. Lithos, 110: 167-180.

Korte, C., Hesselbo, S.P., Jenkyns, H.C., Rickaby, R.E.M., Spötl, C., 2009. Palaeoenvironmental significance of carbon- and oxygen-isotope stratigraphy of marine Triassic-Jurassic boundary sections in SW Britain. Journal of Geological Society, 166: 431-445.

Kozłowska, A., 2004. Diagenesis of the Upper Carboniferous sandstones occurring at the border of the Lublin Trough and the Warsaw Block (in Polish with English summary). Biuletyn Państwowego Instytutu Geologicznego, 411: 5-86.

Kozłowska, A., Poprawa, P., 2004. Diagenesis of the Carboniferous clastic sediments of the Mazowsze region and the northern Lublin region related to their burial and thermal history (in Polish with English summary). Przegląd Geologiczny, 52: 491-500.

Kozur, H.W., Weems, R.E., 2010. The biostratigraphic importance of conchostracans in the continental Triassic of the northern hemisphere. Geological Society Special Publications, 334: 315-417.

Kozydra, Z., Wyrwicki, R., 1977. Preliminary data on the Upper Triassic clays as ceramic raw materials (in Polish with English summary). Biuletyn Instytutu Geologicznego, 299: 149-192.

Kuroda, J., Hori, R.S., Suzuki, K., Gröcke, D.R., Ohkouchi, N., 2010. Marine osmium isotope record across the Triassic-Jurassic boundary from a Pacific pelagic site. Geology, 38: 1095-1098.

Lindström, S., Schootbrugge, B., van de, Dybkjær, K., Pedersen, G.K., Fiebig, J., Nielsen, L.H., Richoz, S., 2012. No causal link between terrestrial ecosystem change and methane release during the end-Triassic mass extinction. Geology, $\mathbf{4 0}$ 531-534.

Lintnerová, O., Michalík, J., Uhlík, P., Soták, J., Weissová, Z., 2013. Latest Triassic climate humidification and kaolinite formation (Western Carpathians, Tatric Unit of the Tatra Mts.). Geological Quarterly, 57 (4): 701-728.

Liu, Z., Wang, H., Hantoro, W.S., Sathiamurthy, E., Colin, C., Zhao, Y., Li, J., 2012. Climatic and tectonic controls on chemical weathering in tropical Southeast Asia (Malay Peninsula, Borneo and Sumatra). Chemical Geology, 291: 1-12.

Marcinkiewicz, T., 1971. The stratigraphy of the Rhaetian and Lias in Poland based on megaspore investigations (in Polish with English summary). Prace Instytutu Geologicznego, 65: 1-58.

Marynowski, L., Simoneit, B.R.T., 2009. Widespread Late Triassic to Early Jurassic wildfire records from Poland: evidence from charcoal and pyrolytic polycyclic aromatic hydrocarbons. Palaios, 24: 785-798.

Marzoli, A., Renne, P.R., Piccirillo, E.M., Bellieni, G., Min, A., de 1999. Extensive 200-million-year-old continental flood basalts of the Central Atlantic Province. Science, 284: 616-618.

Marzoli, A., Bertrand, H., Knight, K. B., Cirilli, S., Buratti, N., Verati, C., Nomade, S., Renne, P. R., Youbi, N., Martini, R., Allenbach, K., Neuwerth, R., Rapaille, C., Zaninetti, L., Bellieni, G., 2004. Synchrony of the Central Atlantic Magmatic Province and the Triassic-Jurassic boundary climatic and biotic crisis. Geology, 32: 973-976.

Marzoli, A., Jourdan, F., Puffer, J.H., Cuppone, T., Tanner, L.H., Weems, R.E., Bertrand, H., Cirilli, S., Bellieni, G., Min, A., de 2011. Timing and duration of the Central Atlantic magmatic province in the Newark and Culpeper basins, eastern U.S.A. Lithos, 122: $175-188$

McElwain, J.C., Beerling, D.J., Woodward, F.I., 1999. Fossil plants and global warming at the Triassic-Jurassic boundary. Science, 285: 1386-1390.

McLennan, S.M., 1993. Weathering and global denudation. Journal of Geology, 101: 295-303. 
Michalik, J., Biron, A., Lintnerova, O., Götz, A., Ruckwied, K., 2010. Climate change at the Triassic-Jurassic boundary in the northwestern Tethyan realm, inferred from sections in the Tatra Mountains (Slovakia). Acta Geologica Polonica, 60: 535-548.

Moiroud, M., Martinez, M., Deconinck, J.-F., Monna, F., Pellenard, P., Riquier, L., Company, M., 2012. High-resolution clay mineralogy as a proxy for orbital tuning: example of the Hauterivian-Barremian transition in the Betic Cordillera (SE Spain). Sedimentary Geology, 282: 336-346.

Moore, D.M., Reynolds, R.C., 1997. X-ray Diffraction and the Identification and Analysis of Clay Minerals. Oxford Univ. Press. New York.

Narkiewicz, M., Resak, M., Littke, R., Marynowski, L., 2010. New constraints on the Middle Palaeozoic to Cenozoic burial and thermal history of the Holy Cross Mts. (Central Poland): results from numerical modelling. Geologica Acta, 8: 189-205.

Nesbitt, H.W., 1979. Mobility and fractionation of rare earth elements during weathering of a granodiorite. Nature, 279: 206-210.

Nesbitt, H.W., Young, G.M., 1982. Early Proterozoic climates and plate motions inferred from major element chemistry of lutites. Nature, 299: 715-717

Nomade, S., Knight, K.B., Beutel, E., Renne, P.R., Verati, C., Feraud, G., Marzoli, A., Youbi, N., Bertrand, H., 2007. Chronology of the Central Atlantic Magmatic Province: Implications for the Central Atlantic rifting processes and the Triassic-Jurassic biotic crisis. Palaeogeography, Palaeoclimatology, Palaeoecology, 244: 326-344.

Nyakairu, G.W.A., Koeberl, C., 2001. Mineralogical and chemical composition and distribution of rare earth elements in clay-rich sediments from central Uganda. Geochemical Journal, 35 13-28.

Olsen, P.E., Kent, D.V., Sues, H.D., Koeberl, C., Huber, H., Montanari, A., Rainforth, E.C., Fowells, J., Szajna, M.J., Hartline, B.W., 2002. Ascent of dinosaurs linked to an iridium anomaly at the Triassic-Jurassic boundary. Science, 296: 1305-1307.

Pálfy, J., Zajzon, N., 2012. Environmental changes across the Triassic-Jurassic boundary and coeval volcanism inferred from elemental geochemistry and mineralogy in the Kendlbachgraben section (Northern Calcareous Alps, Austria). Earth and Planetary Science Letters, 335-336: 121-134.

Pálfy, J., Demény, A., Haas, J., Hetényi, M., Orchard, M.J., Vető, I., 2001. Carbon isotope anomaly and other geochemical changes at the Triassic-Jurassic boundary from a marine section in Hungary. Geology, 29: 1047-1050.

Pieńkowski, G., 2004. The epicontinental Lower Jurassic of Poland. Polish Geological Institute Special Papers, 12: 1-154.

Pieńkowski, G., Schudack, M.E., co-ordinators, 2008. Jurassic. In: The Geology of Central Europe. Volume 2: Mesozoic and Cenozoic (ed. T. McCann): 823-922. Geological Society, London.

Pieńkowski, G., Waksmundzka, M., 2009. Palynofacies in Lowe Jurassic epicontinental deposits of Poland: tool to interpret sedimentary environments. Episodes, 32: 21-32.

Pieńkowski, G., Niedźwiedzki, G., Waksmundzka, M., 2012. Sedimentological, palynological, and geochemical studies of the terrestrial Triassic-Jurassic boundary in north-western Poland. Geological Magazine, 149: 308-332.

Pieńkowski, G., Niedźwiedzki, G., Brański, P., 2014. CAMP-related rapid climatic reversals caused the end-Triassic biota crisis - evidences from continental strata in Poland. GSA Special Paper, 505: 1-24, doi:10.1130/2014.2505(13)

Poprawa, P., 1997. Late Permian to Tertiary dynamics of the Polish Trough. EUROPROBE TESZ-Meeting, Potsdam. Terra Nostra 97: 104-109.

Racki, G., 2010. Climate changes caused by degassing of sediments during the emplacement of large igneous provinces: Comment. Geology, 38: e210.

Raucsik, B., Varga, A., 2008. Climato-environmental controls on clay mineralogy of the Hettangian-Bajocian successions of the Mecsek Mountains, Hungary: an evidence for extreme continen- tal weathering during the early Toarcian oceanic anoxic event. Palaeogeography, Palaeoclimatology, Palaeoecology, 265: $1-13$.

Resak, M., Narkiewicz, M., Littke, R., 2008. New basin modelling results from the Polish part of the Central European Basin system: implications for the Late Cretaceous-Early Paleogene structural inversion. International Journal of Earth Sciences, 97: 955-972.

Retallack, G.J., 2001. Soils of the Past: an Introduction to Paleopedology. Blackwell Science, Oxford.

Richoz, S., Schootbrugge, B., van de , Pross, J., Püttmann, W., Quan, T.M., Lindström, S., Heunisch, C., Fiebig, J., Maquil, R., Schouten, S., Hauzenberger, C.A., Wignall, P.B., 2012. Hydrogen sulphide poisoning of shallow seas following the end-Triassic extinction. Nature Geoscience, 5: 662-667.

Ruffell, A., McKinley, J.M., Worden, R.H., 2002. Comparison of clay mineral stratigraphy to other proxy palaeoclimate indicators in the Mesozoic of NW Europe. Philosophical Transactions of the Royal Society of London, Series A, 360: 675-693.

Ruhl, M., Kürschner, W.M., 2011. Multiple phases of carbon cycle disturbance from large igneous province formation at the Triassic-Jurassic transition. Geology, 39: 431-434.

Ruhl, M., Kürschner, W.M., Krystyn, L., 2009. Triassic-Jurassic organic carbon isotope stratigraphy of key sections in the western Tethys realm (Austria). Earth and Planetary Science Letters, 281: 169-187.

Ruhl, M., Deenen, M.H.L., Abels, H.A., Bonis, N.R., Krijgsman, W., Kürschner, W.M. 2010. Astronomical constraints on the duration of the Early Jurassic Hettangian stage and recovery rates following the end-Triassic mass extinction (St. Audrie's Bay/East Quantoxhead, UK). Earth and Planetary Science Letters, 295: 262-276.

Ruhl, M., Bonis, R.N., Reichart, G.J., Sinninghe-Damsté, J.S., Kürschner, W.M., 2011. Atmospheric carbon injection linked to end-Triassic mass extinction. Science, 333: 430-434.

Schaller, M.F., Wright, J.D., Kent, D.V., 2011. Atmospheric $\mathrm{pCO}_{2}$ perturbations associated with the Central Atlantic Magmatic Province. Science, 331: 1404-1409.

Schaller, M.F., Wright, J.D., Kent, D.V., Olsen, P.E., 2012. Rapid emplacement of the Central Atlantic Magmatic Province as a net sink for $\mathrm{CO}_{2}$. Earth and Planetary Science Letters, 323-324: 27-39.

Schoene, B., Guex, J., Bartolini, A., Schaltegger, U., Blackburn, T., 2010. Correlating the end-Triassic mass extinction and flood basalt volcanism at the 100 ka level. Geology, 38: 387-390.

Schootbrugge, B., van de, Payne, J.L., Tomasovych, A., Pross, J., Fiebig, J., Benbrahim, M., Föllmi, K.B., Quan, T.M., 2008. Carbon cycle perturbation and stabilization in the wake of the Triassic-Jurassic boundary mass-extinction event. Geochemistry Geophysics Geosystems, 9, doi:10.1029/2007GC001914

Schootbrugge, B., van de, Quan, T.M., Lindström, S., Püttmann, W., Heunisch, C., Pross, J., Fiebig J., Petschick, R., Röhling, H.-G., Richoz, S., Rosenthal, Y., Falkowski, P.G., 2009. Floral changes across the Triassic/Jurassic boundary linked to flood basalt volcanism. Nature Geoscience, 2: 589-594.

Self, S., Widdowson, M., Thordarson, T., Jay, A.E., 2006. Volatile fluxes during flood basalt eruptions and potential effects on the global environment: a Deccan perspective. Earth and Planetary Science Letters, 248: 518-532.

Sheldon, N.D., Retallack, G.J., 2002. Low oxygen levels in earliest Triassic soils. Geology, 30: 919-922.

Sheldon, N.D., Tabor, J.N., 2009. Quantitative paleoenvironmental and paleoclimatic reconstruction using paleosols. Earth-Science Reviews, 95: 1-52.

Simms, M.J., 2003. Uniquely extensive seismite from the latest Triassic of the United Kingdom: evidence for bolide impact? Geology, 31: 557-560.

Singer, A., 1984. The palaeoclimatic interpretation of clay minerals in sediments - a review. Earth-Science Reviews, 21: 251-293.

Slujis, A., Brinkhuis, H., Schouten, S., Bohaty, S.M., John, C.M., Zachos, J.C., Sininnghe Damste, J.S., Crouch, E.M., Dick- 
ens, G.R., 2007. Environmental precursors to rapid light carbon injection at the Paleocene/Eocene boundary. Nature, 450 : 1218-1221.

Słowakiewicz, M., Poprawa, P., 2010. Fluid inclusion microthermometry and burial/thermal history modeling combined to reveal hydrocarbon origin and accumulation in the main dolomite (Ca2) rocks of northwestern Poland (well Benice-3) (in Polish with English summary). Biuletyn Państwowego Instytutu Geologicznego, 439: 181-189.

Srivastava, P., Rajak, M.K., Sinha, R., Pal, D.K., Bhattacharyya, T., 2010. A high resolution micromorphological record of the Late Quaternary paleosols from Ganga-Yamuna interfluve: stratigraphic and paleoclimatic implications. Quaternary International, 227: 127-142.

Steinthorsdottir, M., Jeram, A.J., McElwain, J.C., 2011. Extremely elevated $\mathrm{CO}_{2}$ concentrations at the Triassic/Jurassic boundary. Palaeogeography, Palaeoclimatology, Palaeoecology, 308: 418-432.

Stephenson, R.A., Narkiewicz, M., Dadlez, R., Vees, J.-D., van, Andriessen, P., 2003. Tectonic subsidence modeling of the Polish Basin in the light of new data on crustal structure and magnitude of inversion. Sedimentary Geology, 156: 59-79.

Suan, G., Föllmi, K.B., Adatte, T., Bomou, B., Spangenberg, J.E., Schootbrugge, B., van de , 2011. Major environmental change and bonebed genesis prior to the Triassic-Jurassic mass extinction. Journal of Geological Society, 169: 191-200.

Środoń, J., 2006. Identification and quantitative analysis of clay minerals. Developments in Clay Science, 1: 765-787.

Taylor, S.R., McLennan, S.M., 1985. The Continental Crust: its Composition and Evolution. Blackwell Oxford.

Thiry, M., 2000. Palaeoclimatic interpretation of clay minerals in marine deposits: an outlook from the continental origin. Earth-Science Reviews, 49: 201-221.

Tosca, N.J., Johnston, D.T., Mushegian, A., Rothman, D.H., Summons, R.E., Knoll, A.H., 2010. Clay mineralogy, organic carbon burial, and redox evolution in Proterozoic oceans. Geochimica et Cosmochimica Acta, 74: 1579-1592.
Toth, T.A., Fritz, S.J., 1997. An Fe-berthierine from a Cretaceous laterite: Part I, characterization. Clays and Clay Minerals, 45: 564-579.

Ward, P.D., Garrison, G.H., Haggart, J.W., Kring, D.A., Beattie, M.J., 2004. Isotopic evidence bearing on Late Triassic extinction events, Queen Charlotte Islands, British Columbia, and implications for the duration and cause of the Triassic/Jurassic mass extinction. Earth and Planetary Science Letters, 224: 589-600.

Weaver, C.E., 1989. Clays, Muds and Shales. Elsevier, Amsterdam. Whiteside, J., Olsen, P.E., Eglinton, T., Brookfield, M.E, Sambrotto, R.N., 2010. Compound-specific carbon isotopes from Earth's largest flood basalt eruptions directly linked to the end-Triassic mass extinction. Proceedings of the National Academy of Science U.S.A., 107: 6721-6726.

Wiewióra, A., Wyrwicki, R., 1977. Clay minerals in the Upper Triassic sediments in environs of Kluczbork (in Polish with English summary). Kwartalnik Geologiczny, 21: 269-278.

Williford, K.H., Ward, P.D., Garrison, G.H., Buick, R., 2007. An extended organic carbon-isotope record across the Triassic-Jurassic boundary in the Queen Charlotte Islands, British Columbia, Canada. Palaeogeography, Palaeoclimatology, Palaeoecology, 244: 290-296.

Wilson, M., 1997. Thermal evolution of the Central Atlantic passive margins: continental break-up above a Mesozoic super-plume. Journal of Geological Society, 154: 491-495.

Zajzon, N., Kristály, F., Pálfy, J., Németh, T., 2012. Detailed clay mineralogy of the Triassic-Jurassic boundary section at Kendlbachgraben (Northern Calcareous Alps, Austria). Clay Minerals, 47: 177-189.

Zielinski, G.W., Poprawa, P., Szewczyk, J., Grotek, I., Kiersnowski, H., Zielinski, R.L.B., 2012. Thermal effects of Zechstein salt and the Early to Middle Jurassic hydrothermal event in the central Polish Basin. AAPG Bulletin, 96: 1981-1996. 